\title{
Il disegno dei mosaici dell'ambulacro della Grande Caccia nella villa Philosophiana di Piazza Armerina
}

\author{
Giuseppe Di Gregorio
}

Abstract

La villa romana di Pilosohiana o del Casale è la più estesa villa del periodo tardo antico in Sicilia con i suoi 3500 mq di superficie, in prevalenza realizzati tramite apparati musivi in buono stato di conservazione, con un trend di visitatori in continua crescita che ha visto nel 2019 circa 310.550 ingressi. A seguito dei lavori di restauro completati nello scorso decennio per gli apparati musivi, per gli affreschi e per la realizzazione della nuova copertura, rimane una delle mete più ambite per turismo e dei luoghi più studiati con approcci multidisciplinari tra archeologia, architettura, rilievo 3D, idraulica, geologia e ingegneria. Tra tutte le pavimentazioni musive spicca per estensione, decori, fastosità e ricchezza dei temi rappresentati l'ambulacro della grande caccia. Nel presente lavoro si danno i primi risultati ottenuti, attraverso le metodiche del rilievo con Lasers Scanner 3D e fotogrammetria SFM, delle restituzioni grafiche ottenute per alcuni dei contenuti rappresentati nell'apparato musivo dell'impianto pavimentale finalizzati ad una nuova lettura, atteso che recenti studi hanno portato all'attenzione il significato mistico, misterico e velato di alcune parti del mosaico. Tramite metodi e tecnologie viene descritto il percorso del rilievo digitale per ottenere la restituzione grafica del più grande mosaico pavimentale della villa, nonché i primi risultati dell'analisi grafica: segni e gerarchie comunicano un codice investigabile solo con lo strumento grafico del disegno.

Parole chiave

rilievo 3D, rilievo digitale, SFM, fotogrammetria, VR/AR.

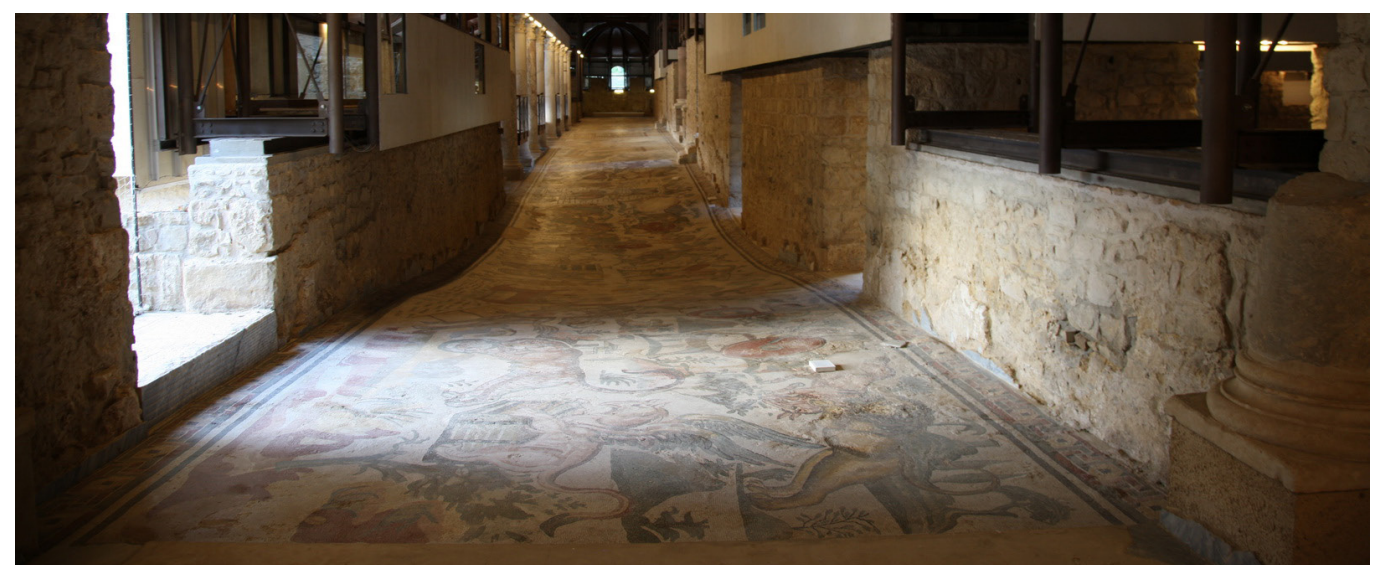




\section{Motivazioni e metodologia}

Nella seconda metà del $X X$ secolo, lungo la costa settentrionale sono state rinvenute diverse ville, riconducibili al III-IV secolo d.C., disposte lungo l'antica via consolare Valeria. Altre tra l'entroterra e la costa sud-orientale, ville con caratteristiche di lussuose residenze suburbane destinate ad esponenti dell'aristocrazia, oggi sono identificate in base alla località: Patti Marina (ME), Bagnoli a Capo d'Orlando (ME), Terme Vigliatore (ME), Settefrati a Cefalù (PA), Lilibeo a Marsala (TP), Durrueli (AG), Geraci (EN), Rasalgone (EN), Tellaro a Noto (SR), Orto Mosaico a Giarratana (RG). La maggior parte in condizioni di ruderi, alcune con apparati musivi parzialmente visibili, altre con apparati traslati in luoghi confinati, non tutte aperte al pubblico. In questo quadro si colloca e spicca la villa romana del Casale con i suoi oltre 3500 mq di superfice, in prevalenza mosaicati, con tutti gli ambienti leggibili nelle loro funzioni (fig. I). Parlando delle ville romane, M. Docci ci dice: "un esempio tipico di questo edificio è rappresentato dalla villa di Piazza Armerina in Sicilia, ove il tema della domus viene ripreso e ampliato.", e più avanti: "lo sfarzo della villa oltre al suo grandioso impianto planimetrico è documentato da preziosi mosaici con scene di vita quotidiana che ornavano i pavimenti di alcune sale" [Docci 1987, p. I I7]. In alcuni ambienti gli apparati musivi sono realizzati con motivi geometrici, in altri con scene monotematiche, ma fra tutti emerge per dimensione, ricchezza formale, sfarzo e molteplicità degli argomenti trattati il mosaico dell'ambulacro bi-absidato della grande caccia con una lunghezza pari a circa $66 \mathrm{~m}$ e una larghezza di circa $6 \mathrm{~m}$, il più esteso apparato musivo in Sicilia per le ville romane e forse non solo per esse. Ancora M. Docci afferma: "Un eccezionale complesso musivo, risalente al IV secolo, è conservato nella villa di Piazza Armerina, in Sicilia. Tra i più notevoli del mondo antico, per la straordinaria ricchezza e varietà delle figurazioni, questi mosaici pavimentali dall'accesa cromia, furono probabilmente opera di maestranze africane" [Docci 1987, p. I22]. Studi recenti hanno affrontato il significato mistico e simbolico della villa, una lettura puntuale viene fornita da R. Giangreco:"sala per sala i soggetti mitologici appartengono a correnti mistiche differenti: questo è l'aspetto più interessante perché è assai raro trovare un così forte sincretismo filosofico-religioso, in un edificio a vocazione apparentemente privata" [Giangreco 20 I2, p. 43]. Attraverso il rilievo digitale, con tecniche di fotogrammetria structure from motion (SFM), laser scanner 3D, sono stati creati modelli tridimensionali su cui potere disegnare le figure dell'apparato musivo, indagano con il disegno le figure, il tipo di proiezione, comprendere le conoscenze degli artefici e ancor di più messaggi mistici, presenti nell'ambulacro della grande caccia.

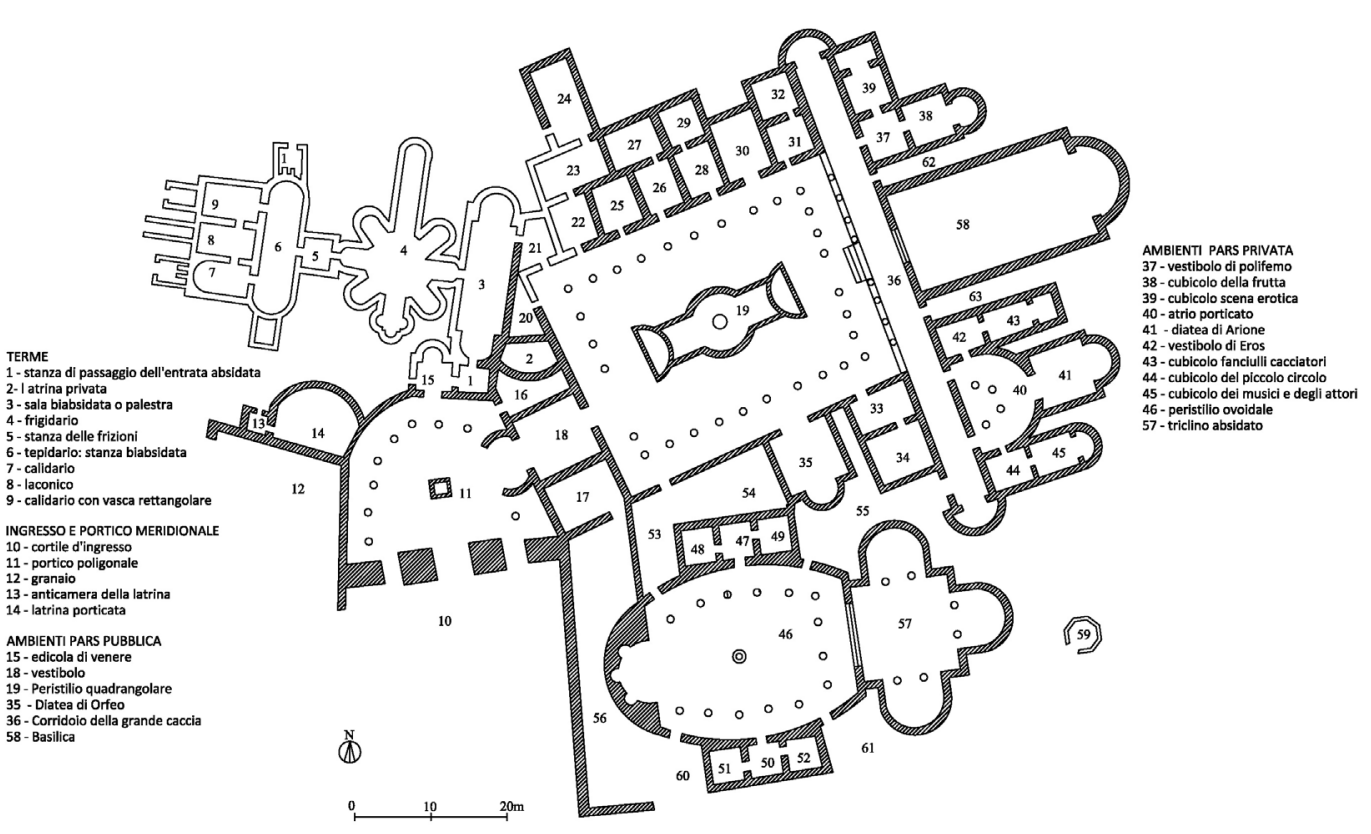


Fig. 2. Ambulacro della grande caccia, dettaglio di ortofoto con
CloudCompare.

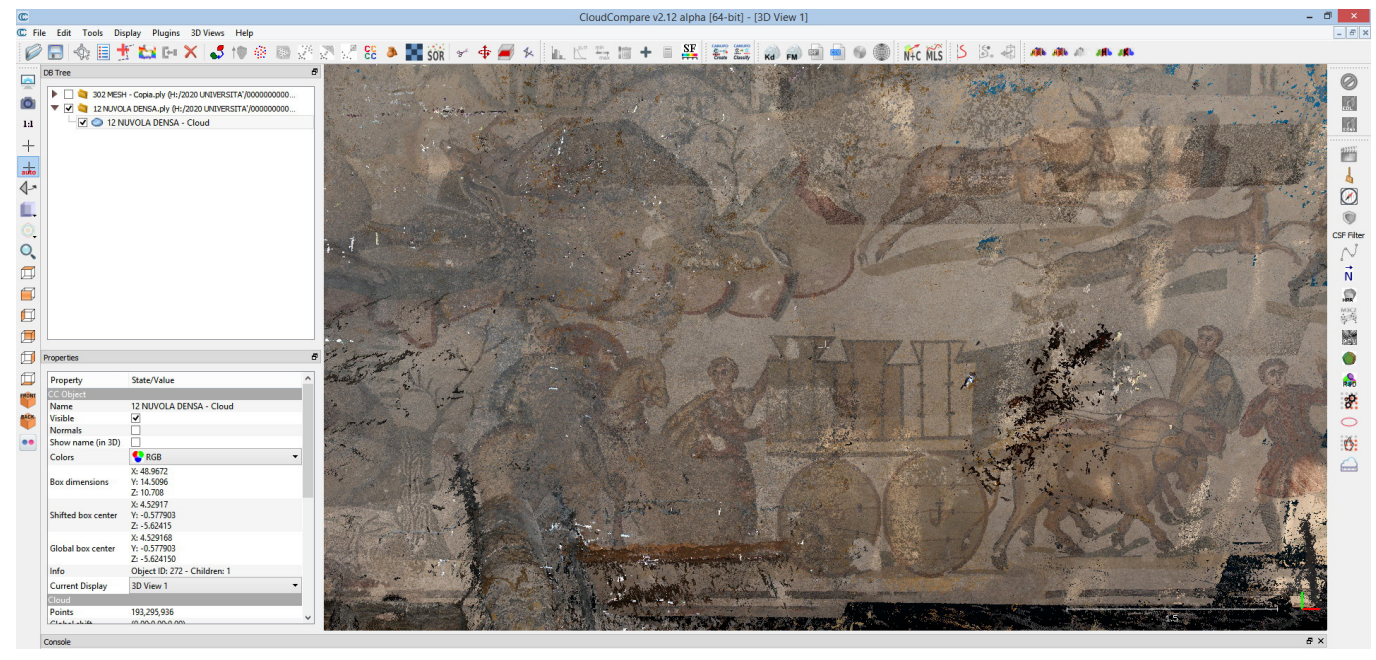

Le campagne degli scavi

Le vicende del rinvenimento prendono awvio nel I88I, con la parte centrale del triclinio e il rinvenimento del mosaico delle fatiche d'Ercole, nel 1929 si ha la ripresa in direzione del ninfeo del portico ovoidale, negli anni ' 40 si inizia a comprenderne la complessità, la ricchezza dei mosaici e degli affreschi, con il rinvenimento della sala tricora. Nel I94I si ha il ritrovamento di altri apparati musivi nel settore nord, nel 1950 la più vasta campagna di scavi che riguarda il portico ovoidale, il rinvenimento del portale monumentale, la zona ad ovest della corte porticata d'ingresso, l'ambulacro della grande caccia e gli ambienti a sud del peristilio. Nel 195I viene concluso lo scavo dell'ambulacro, viene rinvenuto il vestibolo e i portici situati ad est e ad ovest del peristilio. Nel 1952 si concludono i rinvenimenti del portico quadrangolare nel settore nord e prende avvio l'esplorazione della zona termale, seguita da un approfondimento dei rilievi archeologici nella zona a est dell'ambulacro e della basilica. Nel 1955 il rinvenimento e lo studio degli elementi verticali consentono le ipotesi storiche. Tra il 1955 e il 1963 l'area viene messa in sicurezza, e prende avvio il processo di musealizzazione. Nel 1970 una campagna di scavi che contribuisce a stabilire le fasi diacroniche della villa, seguono le campagne tra il 1983 e il 1988, con risultati sulla successione stratigrafica della preesistrente villa rustica. Nel 2004 il rinvenimento a sud di parte dell'abitato medievale. Tra il 2007 e il 20 I 0 il restauro dei mosaici, attualmente sono in corso diversi studi pluridisciplinari.

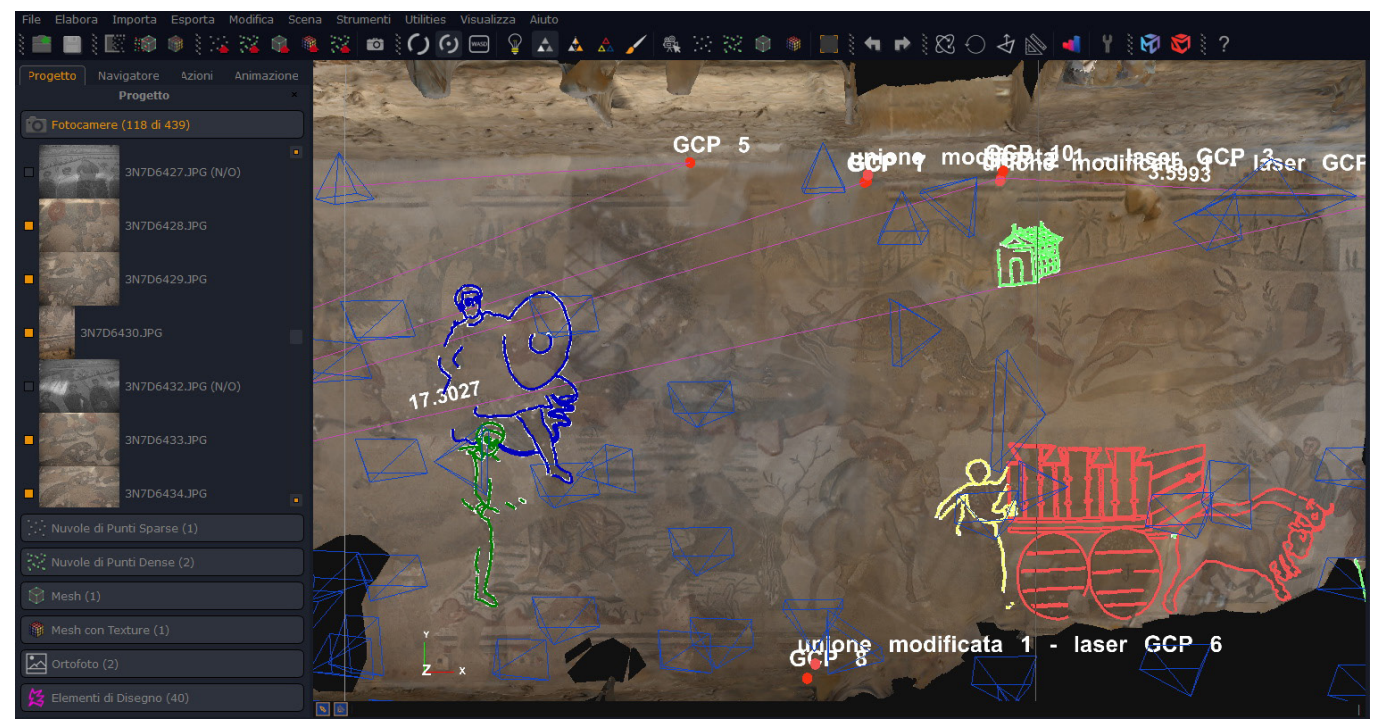

Fig. 3. Ambulacro della grande caccia, punti di controllo, la restituzion grafica di alcune figure con Zephyr. 


\section{La villa nei secoli}

II primo impianto risale al I secolo d.C., ed era comprensivo di una zona produttiva e di una abitativa con una struttura termale successiva, riconducibile al III secolo, posizionata nello strato sottostante l'apparato musivo della palestra. La disposizione della preesistente villa rustica ha inciso sull'orientamento delle terme, della sala triabsidata e del peristilio ovoidale. Altre parti della villa preesistente sono state rinvenute sotto il mosaico dell'ambulacro della grande caccia, ubicato ad est della residenza tardo antica. Altri rinvenimenti nella parte sottostante l'ambiente ad ovest dell'ingresso monumentale e nell'angolo di sud ovest del cortile definito come vestibolo alla latrina del peristilio, ulteriori resti sono visibili all'interno del peristilio. La successiva villa tardoantica è l'impianto di massimo splendore e rappresenta l'apice del suo sviluppo. Appartiene a questo periodo l'imponente apparato decorativo e i fastosi ambienti di rappresentanza nonché l'articolata struttura termale. Molteplici le ipotesi e gli studi ad oggi effettuati, plausibile la teoria che la villa non sia coeva, ma realizzata in più fasi ravvicinate e frutto della stessa concezione architettonica. Si possono distinguere tre fasi edilizie: la prima fase della villa tardo antica coincide con il peristilio quadrangolare e con gli ambienti che si affacciano su di esso; in seguito viene aggiunto l'impianto termale, disposto in direzione nord-ovest, rivolto verso il fiume Gela; successivamente la residenza assume un carattere pubblico: le terme vengono dotate di un nuovo ingresso dall'esterno, viene realizzato il grande ingresso monumentale, in asse con il nuovo ingresso delle terme, con una geometria regolare con il portico ovoidale e la grande sala triabsidata.
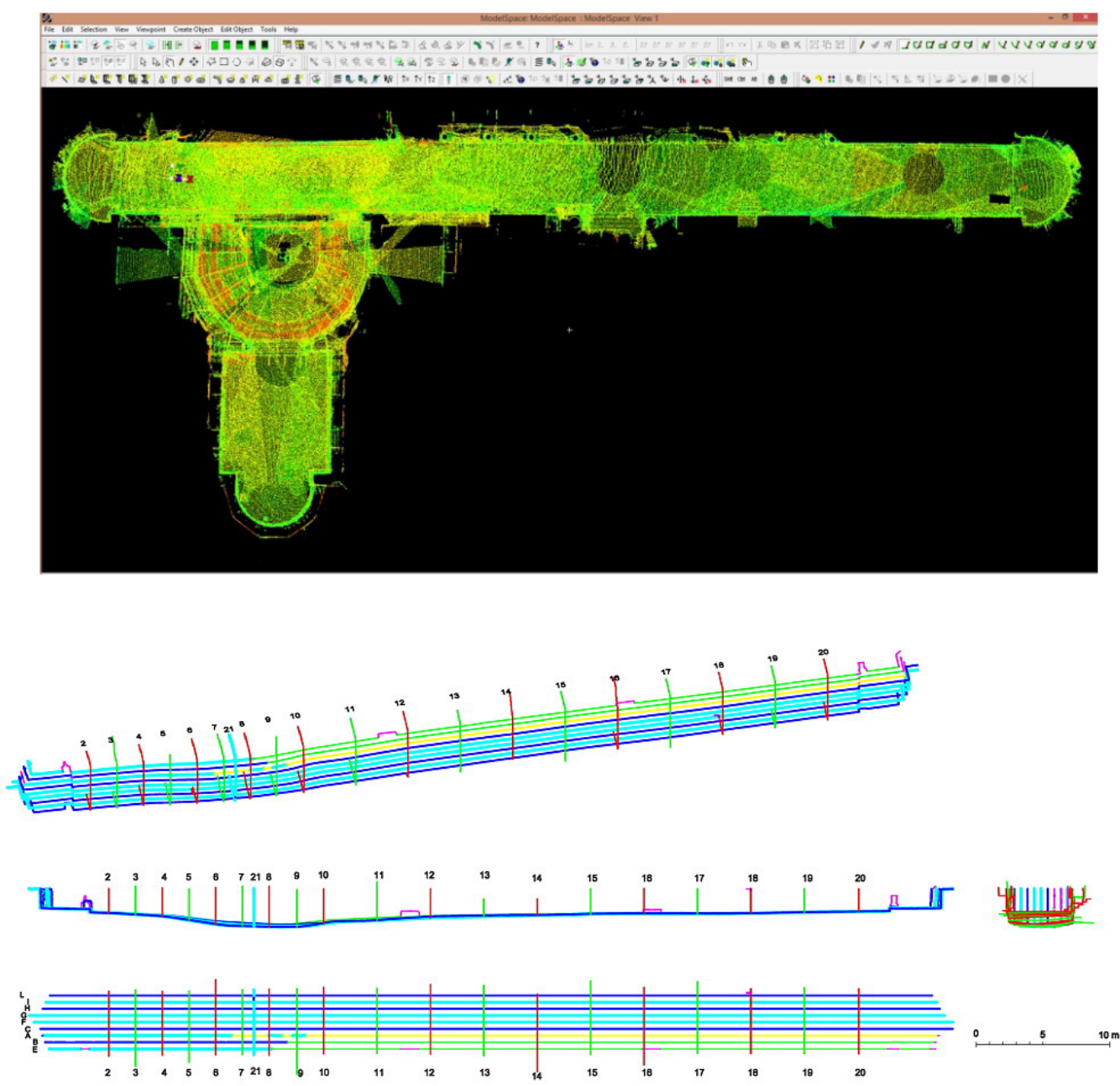
Probabilmente nella terza fase viene anche ampliata la basilica. L'evoluzione lascia intuire che la villa nel corso del IV secolo abbia assunto un ruolo significativo e particolarmente importante, in linea con la natura del committente. L'organizzazione funzionale degli spazi è quella tipica dell'architettura romana tardo-antica, la disposizione su una vasta superficie di un insieme di corpi di fabbrica, disposti a ventaglio [Pellegrino 2007, pp. 33-39]: cinquanta ambienti, raggruppati in quattro complessi distinguibili per le loro funzioni: la palestra con le terme, il peristilio, varie camere adibite a soggiorno con la foresteria, gli ambienti privati con la basilica, la sala tricora e il cortile ellittico.

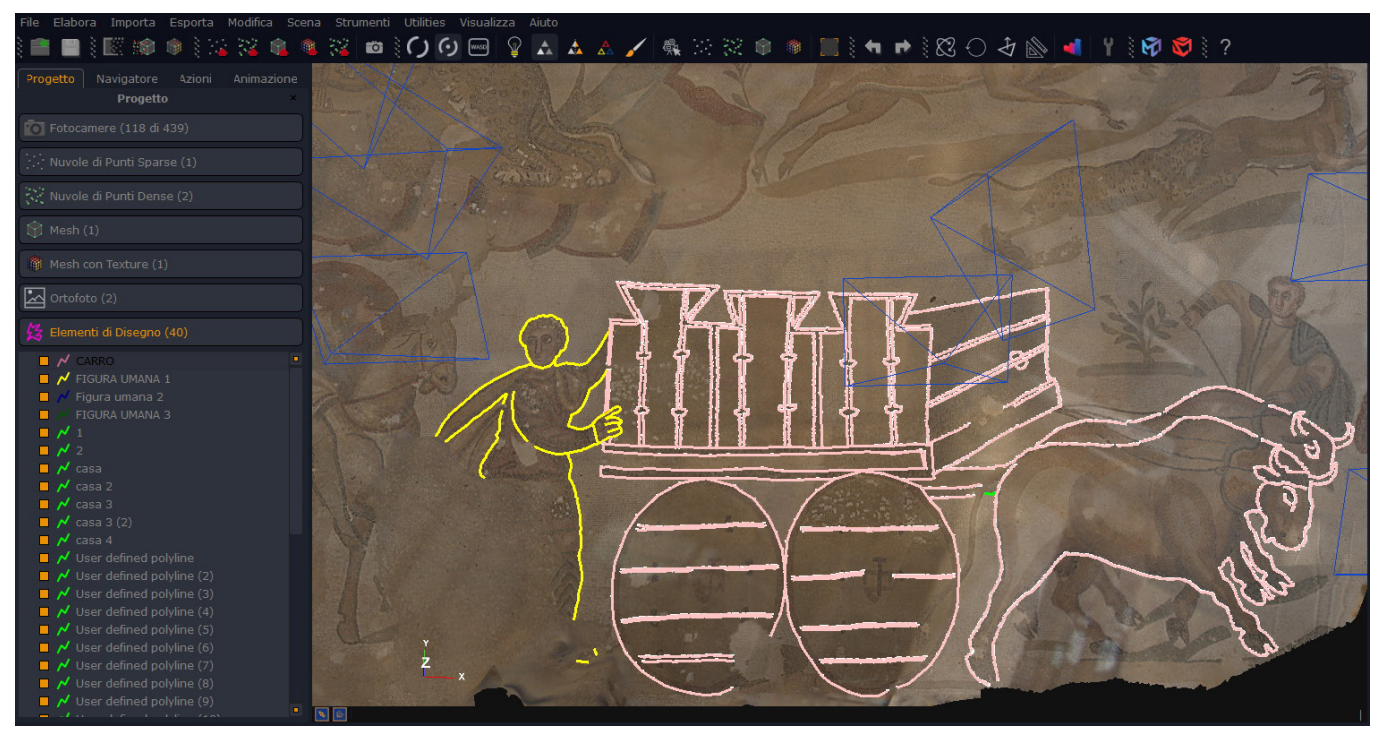

\section{II rilievo}

La tipologia del rilievo è stata determinata dalle condizioni e dall'importanza degli ambienti, per quelli regolari si è ritenuto di utilizzare il rilievo diretto. La fotogrammetria e il laser scanner 3D per quelli con geometrie particolari, quali l'atrio porticato con la diatea di Arione, la basilica, il portico ovoidale, il triclino triabsidato e l'ambulacro della grande caccia, per quest'ultimo la scelta è derivata dalla necessità di approfondire le variazioni di quota del piano di calpestio su cui poggiano i mosaici (fig. 4). Sono stati poi approfonditi alcuni aspetti, tra cui la rappresentazione dei mosaici e la creazione di modelli diVR.

\section{Le rappresentazioni dell'apparato musivo pavimentale dell'ambulacro biabsidato della grande caccia.}

È collocato lungo la parte orientale del peristilio, ad una maggior quota tramite quattro alzate. II nome deriva dal tema del suo mosaico, l'aggettivo per distinguerlo dalla sala della piccola caccia [Sposito 2007, pp. 40-53]. II collegamento con la basilica è ad oltre la metà del suo sviluppo e il loro rapporto non è inscindibile: l'ambulacro rappresenta un elemento di cerniera tra vita pubblica e privata, un preludio all'ambiente più autorevole della villa. II mosaico è impostato su tre registri, di cui il superiore descrive il paesaggio naturale e l'ambiente costruito, l'intermedio descrive alcune scene di caccia e quello inferiore descrive soggetti particolari. Nel presente lavoro verificata la resa grafica del modello SFM dell'intero corridoio rispetto alle dimensioni della pagina si è preferito mostrare solo dettagli di figure e una parte pari a circa un terzo dell'intero sviluppo (fig. I I). Le rappresentazioni contenute risultano divise in 7 scene e 18 riquadri, la lettura procede da nord 
Fig. 6. Ambulacro della grande caccia, restituzione di manufatto con ricerca della profondità.

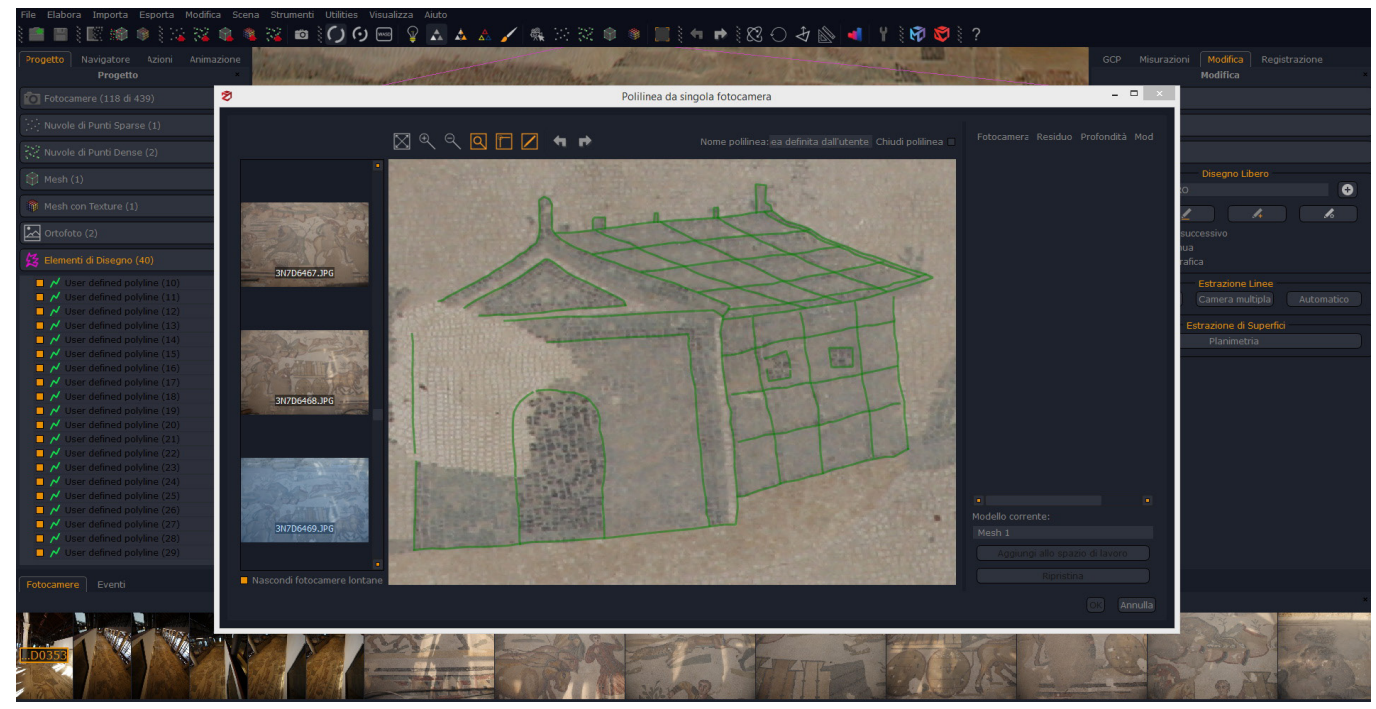

verso l'asse della basilica e da sud verso lo stesso asse. Le rappresentazioni accompagnano il visitatore, con un percorso figurativo fino all'ingresso della basilica, scandito da due colonne poste ad una maggior quota. Le scene da nord verso la basilica possono essere così sintetizzate: I. l'africa, forse la Mauritania, soldati con scudo e la lancia, il leopardo e il leone; 2. le catture di una pantera, dell'antilope, del leone e del cinghiale; 3. struzzi e antilopi, una città (forse Cartagine); 4. il carico di una nave, lo scarico di un elefante in una terra. Nella direzione opposta, da sud, ovvero dall'abside di destra, verso la basilica: 5. I'India con l'elefante asiatico, la tigre femmina; 6. la cattura del grifone con esca umana; 7. la cattura della tigre con la sfera di metallo; 8. una nave che solca il mare; 9. gli animali, belve che divorano un'antilope; I0. un carro trainato dai buoi; I I. la caccia al leone con tre soldati; 12. un rinoceronte e un ippopotamo; 13. un bufalo ed un'antilope nelle paludi del Nilo; I4. I'Egitto con il porto di Alessandria; I5. un elefante una tigre ed un dromedario; 16. una nave che carica un elefante ed attracca in una terra; 17. una terra tra due mari; 18. un'isola: la Sicilia.

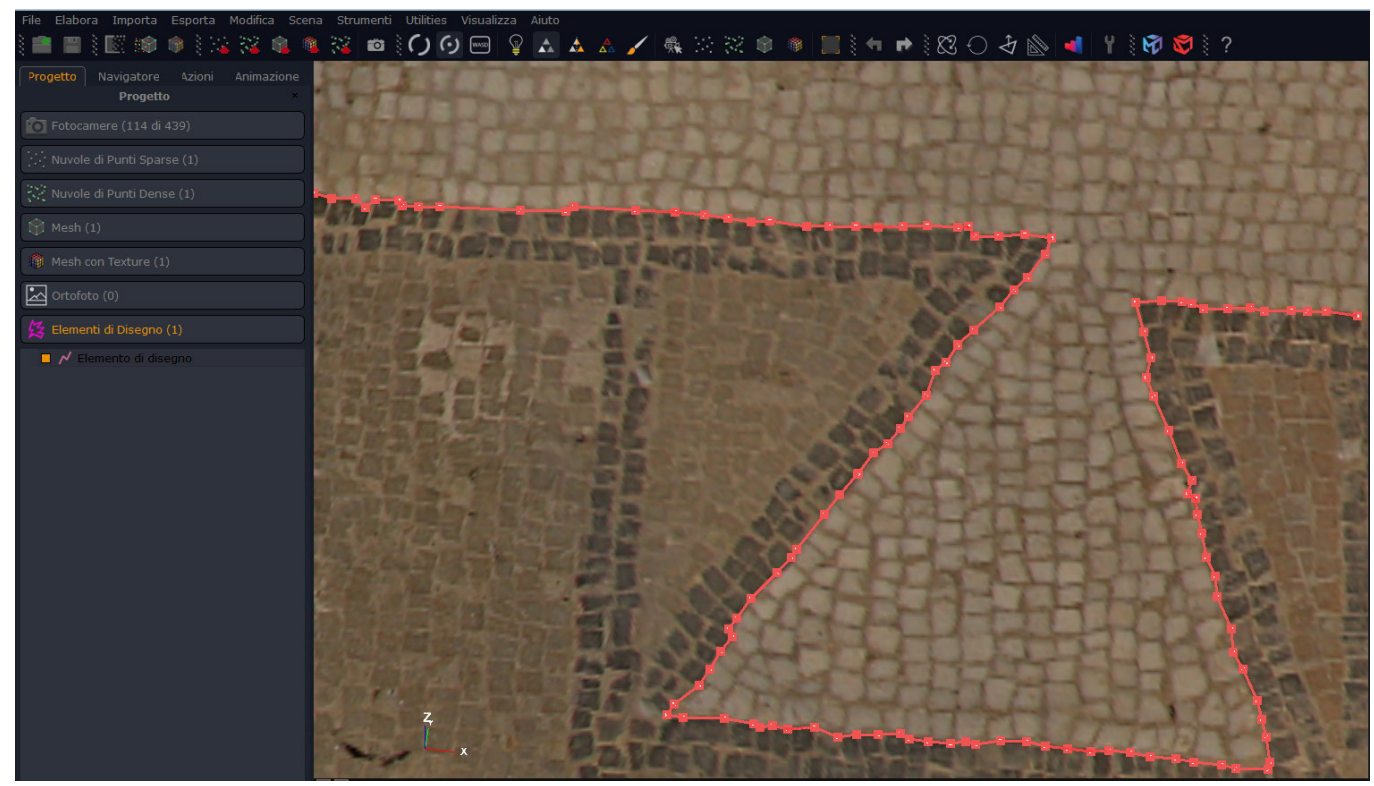


Fig. 8. Ambulacro della grande caccia, i due dignitari con copricapo pannonico e bastone, all'ingresso della basilica, le dimensioni delle figure umane proporzionate alla gerarchia.
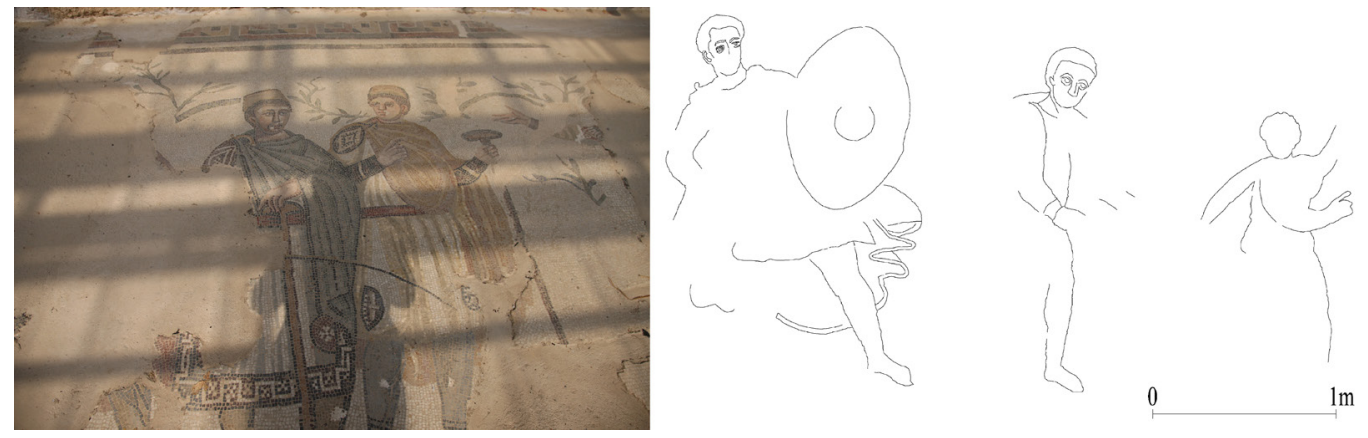

\section{Il rilievo dell'ambulacro della grande caccia e la rappresentazione dell'apparato musivo}

La fotogrammetria utilizzata è quella multimmagine (SFM) validata per una migliore visualizzazione degli apparati musivi, invece con il laser scanner sono state eseguite cinque stazioni (fig.4). Sono stati analizzati diversi workflow:

- $\quad$ utilizzare la nuvola da laser scanner 3D per: eseguire mesh e texture con le immagini del laser scanner; caricare delle foto esterne con un buon dettaglio.

- $\quad$ eseguire il raddrizzamento da singola immagine e comporre un fotomosaico

- $\quad$ eseguire un'elaborazione fotogrammetrica multimmagine SFM, scalata con punti di controllo: disegnare sul modello 3D; generare una ortofoto scalata sui cui disegnare.

- $\quad$ eseguire un'elaborazione fotogrammetrica multimmagine SFM, scalare il modello 3D ottenuto tramite l'unione con la nuvola da laser scanner: disegnare sul modello 3D; generare una ortofoto su cui disegnare.

È stata scartata la prima soluzione in quanto le foto da laser scanner presentano sempre un grado di definizione basso, così pure la procedura di raddrizzamento fotogrammetrico in quanto le dimensioni dell'ambulacro comportano un ricoprimento fotografico notevole, inoltre l'abbassamento del piano di calpestio nella parte meridionale misura valori negativi fino a I,30 metri, situazione poco consona a un raddrizzamento fotografico. Più in generale si è preferito impostare una metodologia automatica accettabile per tempi e precisione, che consentisse un controllo delle fasi di elaborazione, caratteristica tipica delle metodologie SFM. Sono stati utilizzati in prevalenza tre programmi:Zephyr della 3Dflow, Metashape della Agisoft e CloudCompare (fig. 2) [I], ottenendo risultati diversi. L'orientamento preliminare di diversi modelli ha richiesto l'intervento sui parametri per ottenere risultati ottimizzati, coniugati all'allineamento di un maggior numero di fotografie orientate. I risultati migliori hanno visto I I 8 immagini orientate, poi I 30 infine I40 su un set di 452. Si è verificato il GSD medio delle foto panoramiche che è risultato pari a 2,57 $\mathrm{cm} /$ pixel, che costituisce un buon compromesso tra scala grafica dei dettagli delle figure e la dimensione delle tessere pari a circa 5-6 mm nella zona nord e 6-8 $\mathrm{mm}$ in quella sud. Quindi è stata elaborata la nuvola densa, la mesh con 1.342.237 vertici e 2.672.786 triangoli, infine la texture. Per la scalatura del modello sono stati inseriti I I punti di controllo, sono state inserite le distanze tra alcuni di essi e poi verificati gli errori residui. La fase successiva è stata quella di unire
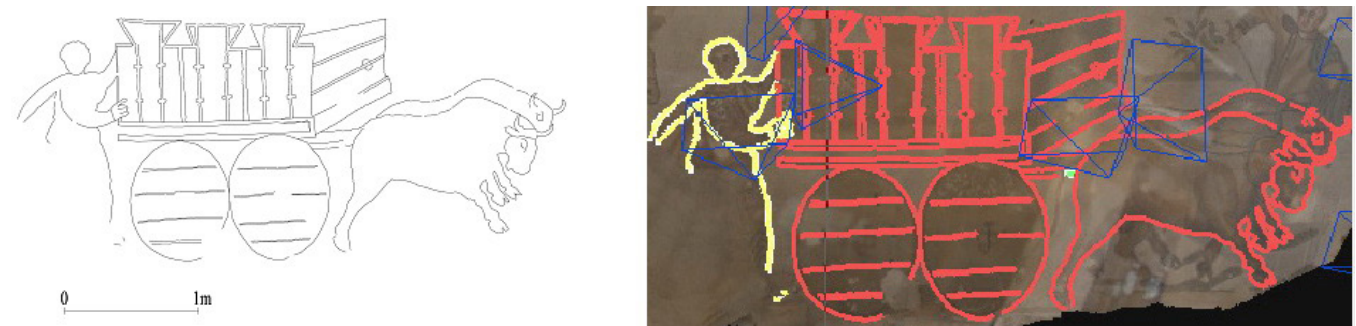
la nuvola SFM ricavata dalle foto con quella del laser scanner 3D, tramite il software Zephyr. Sono stati registrati 10 punti di controllo (fig. 3) omologhi ai primi dieci della nuvola fotogrammetrica elaborata in precedenza. È stato eseguito l'allineamento grezzo tra le due nuvole mediante i punti di controllo omologhi, quindi l'allineamento di precisione ICP,l'errore residuo massimo tra le due nuvole è risultato pari a $2 \mathrm{~mm}$.

Fig. 10. Ambulacro della grande caccia, la ricerca della profondità nella rappresentazione del costruito.
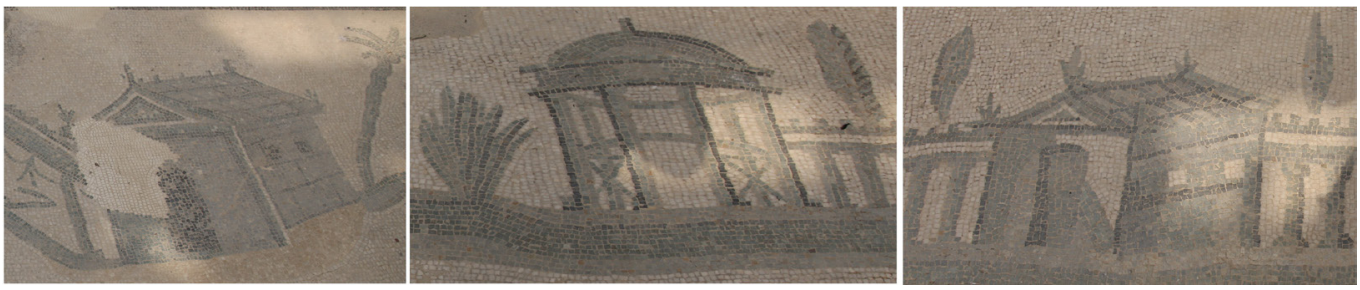

Fig. I I. Ambulacro della grande caccia, il modello SFM di circa un terzo de corridoio a partire dal lato nord.

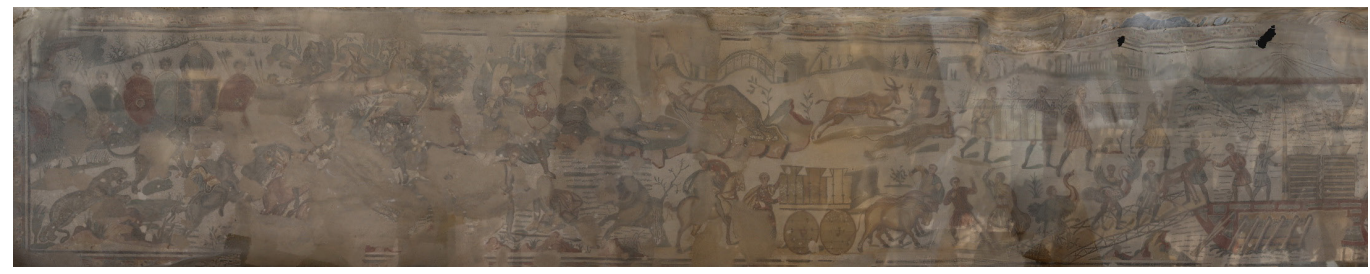

\section{La restituzione grafica}

La restituzione è stata impostata sul modello tridimensionale (fig. 3), piuttosto che su ortofoto, in quanto l'edit grafico di Zephyr consente di disegnare sia sul modello tridimensionale elaborato come mesh con texture, che sulle singole foto (fig.6), opportunità molto utile che consente di seguire i contorni secondo la qualità dell'immagine. La modalità di tracciamento su Zephyr prevede la creazione di una polilinea, per cui si è seguito il bordo delle figure in due modalità differenti, quanto si è presentato irregolare, il tracciamento ha seguito la singola tessera del mosaico, nel caso di un bordo regolare gli step di registrazione sono stati maggiori (fig. 7). La restituzione è stata organizzata in layer per distinguere le varie figure umane (fig. 8) e gli oggetti, tra questi sono stati restituiti inizialmente i carri con gli animali da traino (figg. 5, 9) e dei semplici manufatti (figsg. 6, 10). Dalla nuvola ottenuta mediante laser scanner sono stati tracciati diversi profili per studiare le variazioni di quota del piano di calpestio (fig. 4).

\section{I risultati ottenuti}

Nella villa romana di Philosophiana tutto è legato ai riti misterici, tutto è simbolo, in ogni ambiente viene trattato uno dei diversi misteri. Nella diatea di Orfeo il tema dell'iconografia musiva è centrata sull'orfismo, nel triclinio il rito di Dionisio, Eros e Pan nel vestibolo, così nell'ambulacro della grande caccia il tema dominante è il mitraismo legato al culto orientale di Mitras. Inoltre si possono individuare dei particolari da collegare solo a fiduciari o comunque membri del seguito imperiale, recenti studi condotti in occasione del XVI Convegno dell'AISCOM [2], hanno ipotizzato che i proprietari della villa potrebbero essere stati due prefetti romani, padre e figlio, l'ipotesi deriva da un attentissimo studio del mosaico, in cui comparirebbe un anziano personaggio con un copricapo pannonico, simbolo di potere e un altro accanto adornato allo stesso modo, entrambi all'ingresso alla basilica. Si tratterebbe di Ceionius Rufus Volusianus, praefectus urbis e console, al tempo di Massenzio e Costantino, e il figlio Ceionius Rufus Albinus (fig. 8), noto per le proprie qualità intellettuali, tanto da meritare l'epiteto di philosophus. Oltre al copricapo, uno dei due reca in mano il bastone a tau, simbolo di comando autorità oltre che di predestinazione, che trova un'analogia semantica in un 
personaggio di un'altra villa, quella del Tellaro nel territorio di Noto (SR). II bastone ricorda i misteri eleusini, esempio di sincretismo culturale tra misteriosofie differenti come l'anticosmico orfismo e il mitraismo. Ancora la clamide con all'altezza del braccio destro un rombo inscritto in una circonferenza con ben otto punti scanditi dai lati del rombo che indicano il raggiungimento della perfezione: l'ottava porta oltre le sette sfere. Al personaggio più anziano viene attribuita la caratteristica del proprietario, una sorta di sacerdote, maestro, filosofo che una volta ricordate, attraverso le allegorie della caccia, le traversie superate per raggiungere l'elevazione spirituale si preparava ad entrare nella basilica per celebrare solenni liturgie da condividere con i membri dell'elite intellettuale e spirituale. Senza voler oltre disquisire su altri personaggi e simbolismi pur presenti si comprende come l'analisi grafica di quest'apparato musivo consenta una lettura finora inusitata. I primi risultati hanno consentito di stabilire: I'esistenza di una gerarchia dei personaggi descritta tramite differenti misure delle figure umane, la ricerca della terza dimensione in alcuni manufatti architettonici (fig. I0) piuttosto che in altri, un aspetto che da significato ai luoghi, una ricerca di profondità che esalta alcuni oggetti. La differenza dimensionale tra le figure umane si basa sulla gerarchia sociale, le dimensioni sono crescenti secondo il rango, ma anche la cura dei dettagli e la sontuosità degli ornamenti. Sono tre le gerarchie (fig. 8): i servili, i soldati e gli aristocratici, anche i rapporti fra le varie parti del corpo rientrano in dei parametri di armonie dimensionali. Le figure umane sono rappresentate in prevalenza in posizioni dinamiche, nell'atto di compiere un'azione, il corpo in vista frontale per dare più spazio possibile alla rappresentazione dell'abbigliamento, il viso per alcune in vista frontale per altre di profilo. Riguardo al costruito, il senso della profondità nel disegno predilige alcuni oggetti che sono rappresentati in una sorta di assonometria con il prospetto non deformato (fig. I 0), altri solo in proiezione frontale. Tra quelli in assonometria in alcuni vi è un'attenzione per l'attacco a terra nel senso della profondità, per altre rappresentazioni la questione è risolta in maniera sbrigativa, diverse potrebbero essere le ipotesi di questo dualismo: un rifacimento tardivo, diverse maestranze con differenti conoscenze. Altra rispondenza grafica è stata la dimensione e la posizione dei due personaggi aristocratici rispetto la scalinata d'accesso alla basilica, nonché la corretta geometria del rombo sul braccio destro delle due figure aristocratiche e di altri personaggi. In approfondimenti futuri saranno studiati gli aspetti materici e colorimetrici delle tessere, si cercheranno analogie e differenze con mosaici coevi nella medesima aerea tra cui la villa del Tellaro, nonché la restituzione grafica degli altri ambienti della villa per le analogie dimensionali e formali delle figure e dei simboli esoterici. A partire dalle piante è stato creato un modello digitale tridimensionale della villa con SketchUp (fig. I2), navigabile da PC e utilizzabile con visori e smartphone, è in corso lo sviluppo di un modello su Oculus Quest 2 e la creazione di una realtà immersiva tramite due cave differenti con due workflow differenti. La prima cave è a tre pareti, è gestita da IEMEST [3] ed è in corso di costruzione prevede l'utilizzo di Meshlab e Unity3D, superandone i problemi con il plugin Uni-CAVE. La seconda cave già operativa è stata sviluppata da SWING IT [4], è due pareti in corso di ampliamento per la terza parete e prevede l'utilizzo di TechViz oltre l'utilizzo di periferiche indossabili per un'interazione immersiva.

\section{Conclusioni}

L'attività di ricerca della villa romana di Philosophiana, coinvolge sempre più saperi e settori disciplinari, indagando nuovi aspetti. Nel più grande apparato musivo della villa sono rappresentate scene di caccia nel rapporto con i tre continenti del mediterraneo, nel cui centro si trova l'isola di Sicilia, nel cui centro si trova la villa, nel cui centro si trova il mosaico. La lettura di questo apparato musivo che cattura da sempre l'attenzione, svela dei messaggi sottesi leggibili attraverso lo strumento grafico. L'attività di ricerca sopra descritta è ancora in corso con ulteriori sviluppi tra cui l'intenzione di una ripresa con drone per una migliore qualità del ricoprimento fotogrammetrico e l'avvio della stessa indagine nei mosaici tra i più ambiziosi degli altri ambienti. Ulteriori iniziative di virtualizzazione dei mosaici e dell'intera villa sono stati intrapresi per l'elaborazione di realtà virtuale (VR) e realtà aumentata (AR), nell'ambito di un progetto finanziato dalla regione Sicilia. 
Fig. I 2. La villa del casale il modello 3D creato con SketchUp, navigabile con PC e utilizzabile con smartphone e visori.

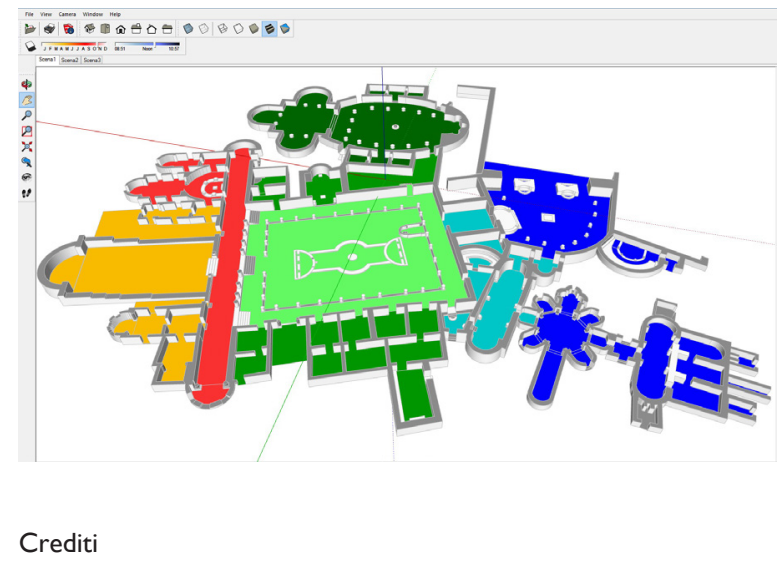

Questo lavoro è stato sostenuto dal progetto "Creazione di una rete regionale per l'erogazione di servizi innovativi basati su tecnologie avanzate di visualizzazione" (3DLab-Sicilia), n. 08CT4669990220, finanziato dal Programma Operativo 20I4-2020 del Fondo Europeo di Sviluppo Regionale (FESR) della Regione Siciliana.

\section{Note}

[I] II software Zephyr è della 3Dflow, Metashape della Agisoft e sono marchi registrati. CloudCompare è definito da una GNU General Public License (GPL).

[2] Associazione Italiana per lo studio e la conservazione dei Mosaici.

[3] IE.ME.S.T. - Istituto Euro Mediterraneo di Scienza e Tecnologia di Palermo, è uno dei partner del progetto 3DLAB SICILIA

[4] SWING IT è l'acronimo o l'abbreviazione di Software Engineering con sede a San Giovanni La Punta (CT), è uno dei partner del progetto 3DLAB SICILIA.

\section{Riferimenti bibliografici}

Benedetti B., Gaiani M., Remondino F. (20 I0). Modelli digitali 3D in archeologia: il caso di Pompei. Pisa: EAN.

Cammarata E. (20 I6). L'antica Villa Romana del Casale di Piazza Armerina Verità Storiche e Curiosità. Messina: Edizione Avvenire.

Docci M. (1987). Disegno e Analisi Grafica, Preistoria Grecia Roma. Bari: Laterza.

Farella E.M.R. Torresani A., Remondino F., (2019), Quality Features for integration of and UAV Images, Int. Arch. Photogramm. In Remote Sens. Spatial Inf. Sci, n. XLII-2NW9, pp. 339-346.

Giangreco R. (20 I2). Villa Romana del Casale Viaggio tra i misteri. Assoro (EN): NovaGraf.

Grilli E., Remondino F. (2019). Classification of 3D Digital Heritage. In Remote Sens., n. I I, p. 847.

Meli G. (a cura di). (2007). La villa e gli apparati decorativi, Progetto di recupero e conservazione della Villa Romana del casale di Piazza Armerina, Centro Regionale per la progettazione e il Restauro. Palermo: CIP.

Pensabene P., Barresi P. (a cura di). (2019). Piazza Armerina Villa del Casale, scavi e studi nel decennio 2004-20 I4. Roma: «L'ERMA» di BRETSCHNEIDER.

Settis S. (1975). Per l'interpretazione di Piazza Armerina. In Melange de l'Ecole francaise de Rome, n. 87(2) LXXXVII, pp. $873-994$ <https://www.persee.fr/doc/mefr_0223-5102_1975_num_87_2_5460> (consultato il 5 February 202I).

Sposito A. (2007), L'Architettura della Villa del Casale, L'Ambulacro Biabsidato della grande Caccia. In Meli G. (a cura di). La villa e gli apparati decorativi. Progetto di recupero e conservazione della Villa Romana del casale di Piazza Armerina. Centro Regionale per la progettazione e il Restauro, CIP - Biblioteca centrale della Regione siciliana "Alberto Bombace", Palermo.

\section{Autore}

Giuseppe Di Gregorio, Università degli Studi di Catania, giuseppe.digregorio@unict.it

Per citare questo capitolo: Di Gregorio Giuseppe (2021). Il disegno dei mosaici dell'ambulacro della Grande Caccia nella villa Philosophiana di Piazza Armerina/ The Drawing of the Mosaic Ambulatory of the Great Hunt in the Philosophiana Villa in Piazza Armerina. In Arena A. Arena M., Mediati D. Raffa P. (a cura di). Connettere. Un disegno per annodare e tessere Linguaggi Distanze Tecnologie. Atti del $42^{\circ}$ Convegno Internazionale dei Docenti delle Discipline della RoppresentazionelConecting. Drawing for weoving relationship. Languges Distances Technologies Proceedings of the 42th International Conference of Representation Disciplines Teachers. Milano: FrancoAngeli, pp. 221 I-2230. 


\title{
The Drawing of the Mosaic Ambulatory of the Great Hunt in the Philosophiana Villa in Piazza Armerina
}

\author{
Giuseppe Di Gregorio
}

Abstract

The Roman villa of Pilosohiana or del Casale is the largest villa of the late antique period in Sicily with its 3500 square meters of surface, mainly made with mosaic apparatuses in a good state of conservation, with a growing trend of visitors that has seen approximately 310,550 admissions in 2019 . Following the restoration work completed in the last decade for the mosaic apparatus, for the frescoes and for the construction of the new roof, it remains one of the most sought-after destinations for tourism and the most studied places with multidisciplinary approaches between archeology, architecture, 3D relief, hydraulics, geology and engineering. Among all the mosaic floors, the ambulatory of the great hunt stands out for its extension, decorations, splendor and richness of the themes represented. In this work, the first results obtained, through the methods of surveying with 3D Lasers Scanner and SFM photogrammetry, are given of the graphic returns obtained for some of the contents represented in the mosaic apparatus of the floor system aimed at a new reading, given that recent studies have brought to attention the mystical, mysterious and veiled meaning of some parts of the mosaic. Using methods and technologies, the path of the digital survey is described to obtain the graphic rendering of the largest floor mosaic of the villa, as well as the first results of the graphic analysis: signs and hierarchies communicate a code that can only be investigated with the graphic tool.

Keywords

3D survey, digital survey, SFM, photogrammetry, VR/AR.

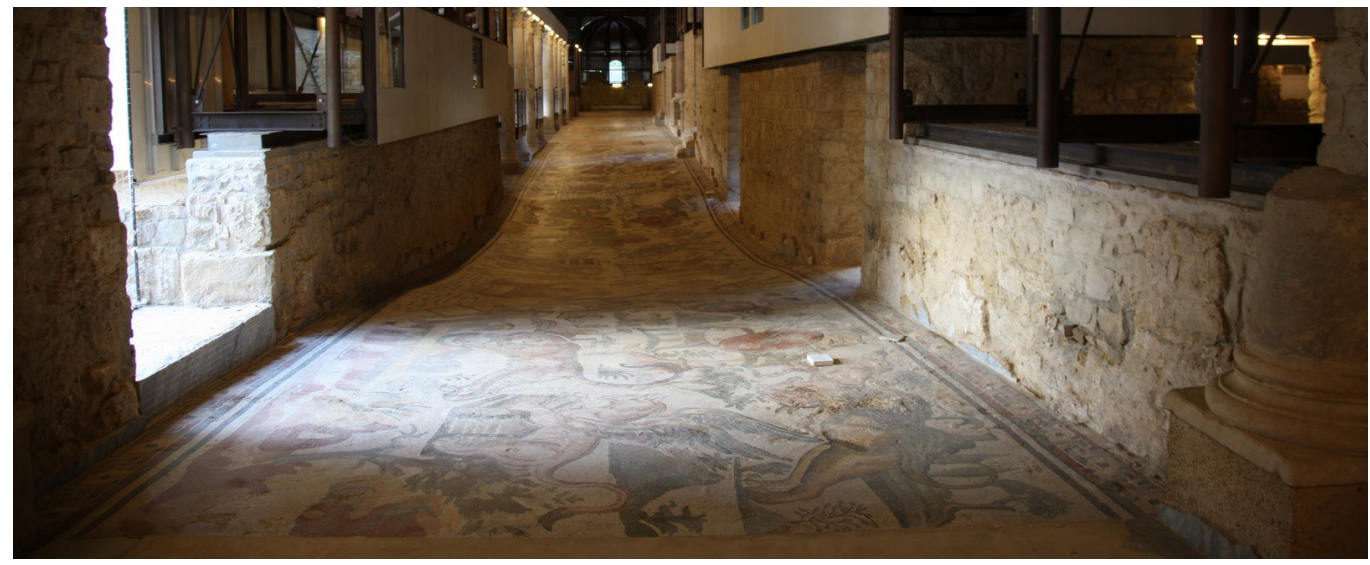




\section{Motivations and methodology}

In the second half of the twentieth century, several villas were found along the northern coast, dating back to the III-IV century AD, arranged along the ancient consular road Valeria. Others between the hinterland and the south-eastern coast, villas with the characteristics of luxurious suburban residences intended for members of the aristocracy, are today identified by location: Patti Marina (ME), Bagnoli in Capo d'Orlando (ME), Terme Vigliatore (ME), Settefrati in Cefalù (PA), Lilibeo in Marsala (TP), Durrueli (AG), Geraci (EN), Rasalgone (EN), Tellaro in Noto (SR), Orto Mosaico in Giarratana (RG). Most of them are in ruins, some with partially visible mosaic arrays, others with arrays moved to confined places, not all open to the public. The Roman villa of Casale stands out in this context with its over 3500 square meters of surface, mainly mosaics, with all the rooms legible in their functions (fig. I). Speaking of the Roman villas, M. Docci tells us: "a typical example of this building is represented by the villa in Piazza Armerina in Sicily, where the theme of the domus is taken up and expanded.", and further on: "the splendor of the villa in addition to its grandiose planimetric layout is documented by precious mosaics with scenes of daily life that adorned the floors of some rooms" [Docci 1987, p. I I 7]. In some rooms the mosaic arrangements are made with geometric motifs, in others with monothematic scenes, but among all the mosaic of the double apsidal ambulatory of the great hunt emerges in terms of size, formal richness, splendor and multiplicity of the topics covered, with a length of about $66 \mathrm{~m}$ and a width of about $6 \mathrm{~m}$, the largest mosaic apparatus in Sicily for Roman villas and perhaps not only for them. Again M. Docci affirms: "An exceptional mosaic complex, dating back to the 4th century, is preserved in the villa in Piazza Armerina, in Sicily. Among the most notable of the ancient world, for the extraordinary richness and variety of the figurations, these floor mosaics with their bright colors, were probably the work of African craftsmen" [Docci 1987, p. I22]. Recent studies have dealt with the mystical and symbolic significance of the villa, a precise reading is provided by R. Giangreco: "room by room the mythological subjects belong to different mystical currents: this is the most interesting aspect because it is very rare to find such a strong philosophical-religious syncretism, in a building with an apparently private vocation" [Giangreco 20 I2, p.43]. Through digital survey, with structure from motion (SFM) photogrammetry techniques, 3D laser scanner, three-dimensional models have been created on which to draw the figures of the mosaic apparatus, investigate the figures with the drawing, the type of projection, understand the knowledge of the makers and even more mystical messages, present in the ambulatory of the great hunt.

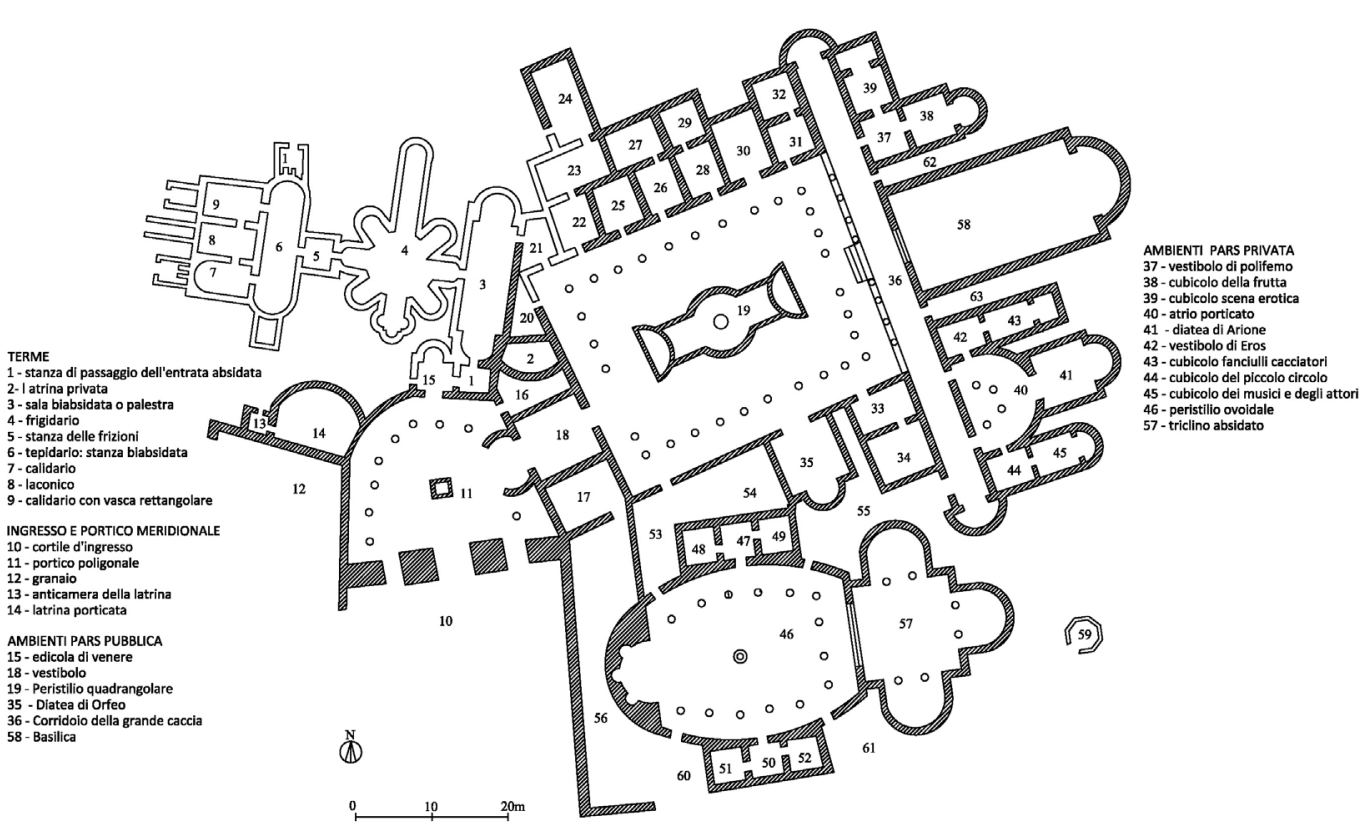




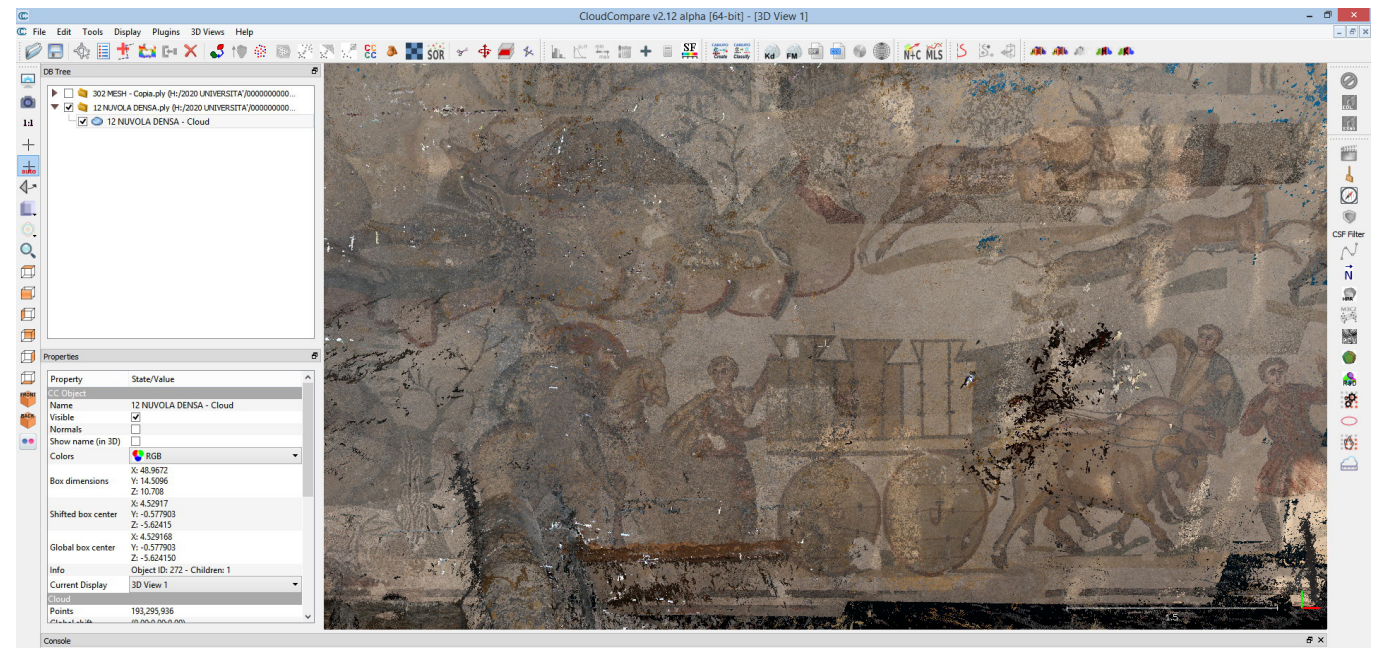

\section{The excavation campaigns}

The events of the discovery began in $|88|$, with the central part of the triclinium and the discovery of the mosaic of the labors of Hercules, in 1929 there was the resumption of the ovoid portico in the direction of the nymphaeum, in the 40s we began to understand its complexity, the richness of the mosaics and frescoes, with the discovery of the tricora room. In 194 I other mosaic artifacts were found in the northern sector, in 1950 the largest excavation campaign involving the ovoid portico, the discovery of the monumental portal, the area to the west of the porticoed entrance court, the ambulatory of the large hunting and the rooms south of the peristyle. In 195I the excavation of the ambulatory was completed, the vestibule and arcades located east and west of the peristyle were found. In 1952 the findings of the quadrangular portico in the northern sector were completed and the exploration of the spa area began, followed by an in-depth study of the archaeological findings in the area east of the ambulatory and the basilica. In 1955 the discovery and study of the vertical elements allow historical hypotheses. Between 1955 and 1963 the area was made safe, and the museumization process began. In 1970 an excavation campaign that helps establish the diachronic phases of the villa followed the campaigns between 1983 and 1988, with results on the stratigraphic succession of the pre-existing rustic villa. In 2004, the discovery of part of the medieval town to the south. Between 2007 and 2010 the restoration of the mosaics, several multidisciplinary studies are currently underway.

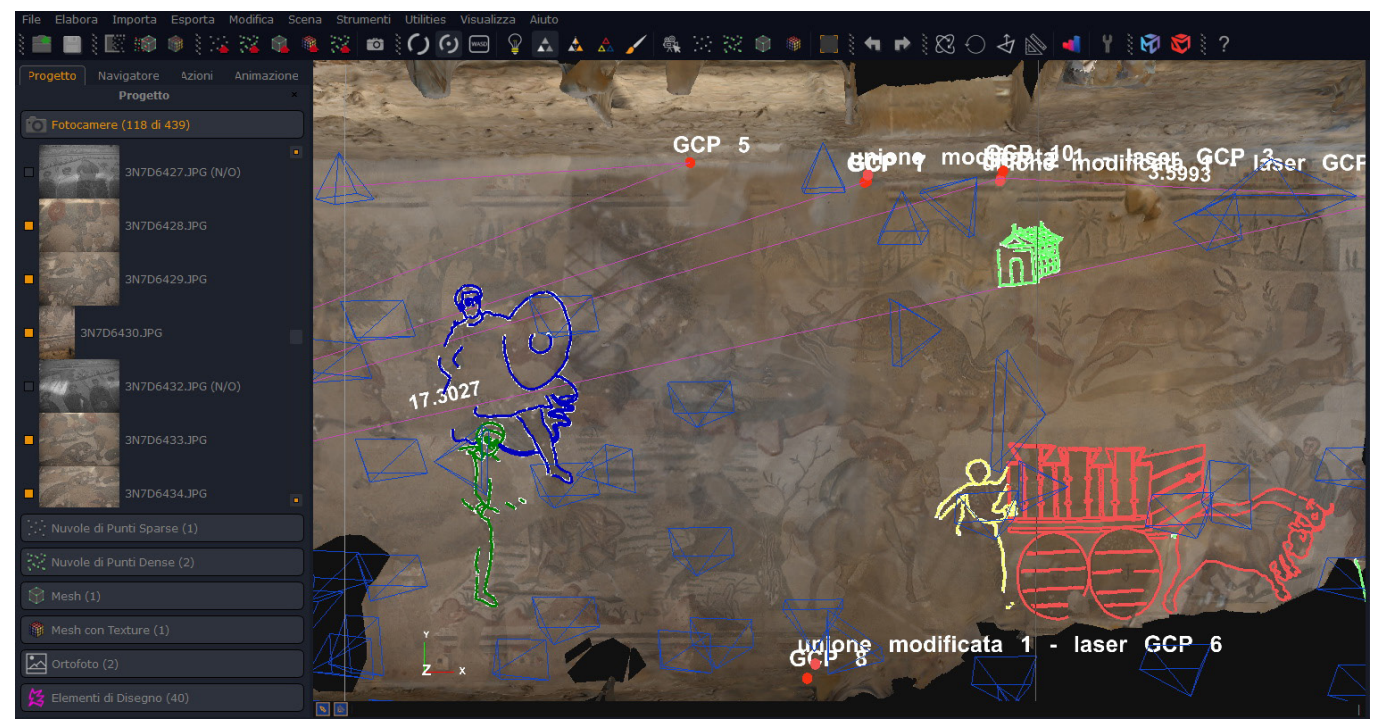




\section{The villa through the centuries}

The first plant dates back to the Ist century AD, and included a production area and a residential area with a subsequent spa structure, attributable to the $3 r d$ century, positioned in the layer below the mosaic apparatus of the gymnasium. The layout of the pre-existing rustic villa has affected the orientation of the baths, the triapsidal room and the ovoid peristyle. Other parts of the pre-existing villa were found under the mosaic of the ambulatory of the great hunt, located east of the late antique residence. Other findings in the part below the room west of the monumental entrance and in the southwest corner of the courtyard defined as the vestibule to the latrine of the peristyle, further remains are visible inside the peristyle. The subsequent late antique villa is the plant of maximum splendor and represents the apex of its development. The imposing decorative apparatus and the sumptuous representative rooms as well as the articulated spa structure belong to this period. Numerous hypotheses and studies carried out to date, the theory that the villa is not contemporary, but built in several close phases and the result of the same architectural concept.

Three building phases can be distinguished: the first phase of the late ancient villa coincides with the quadrangular peristyle and with the rooms that overlook it; later, the thermal plant is added, arranged in a north-west direction, facing the Gela river; subsequently the residence takes on a public character: the baths are equipped with a new entrance from the outside, the large monumental entrance is created, in line with the new entrance to the baths, with a regular geometry with the ovoid portico and the large triapsidal hall.
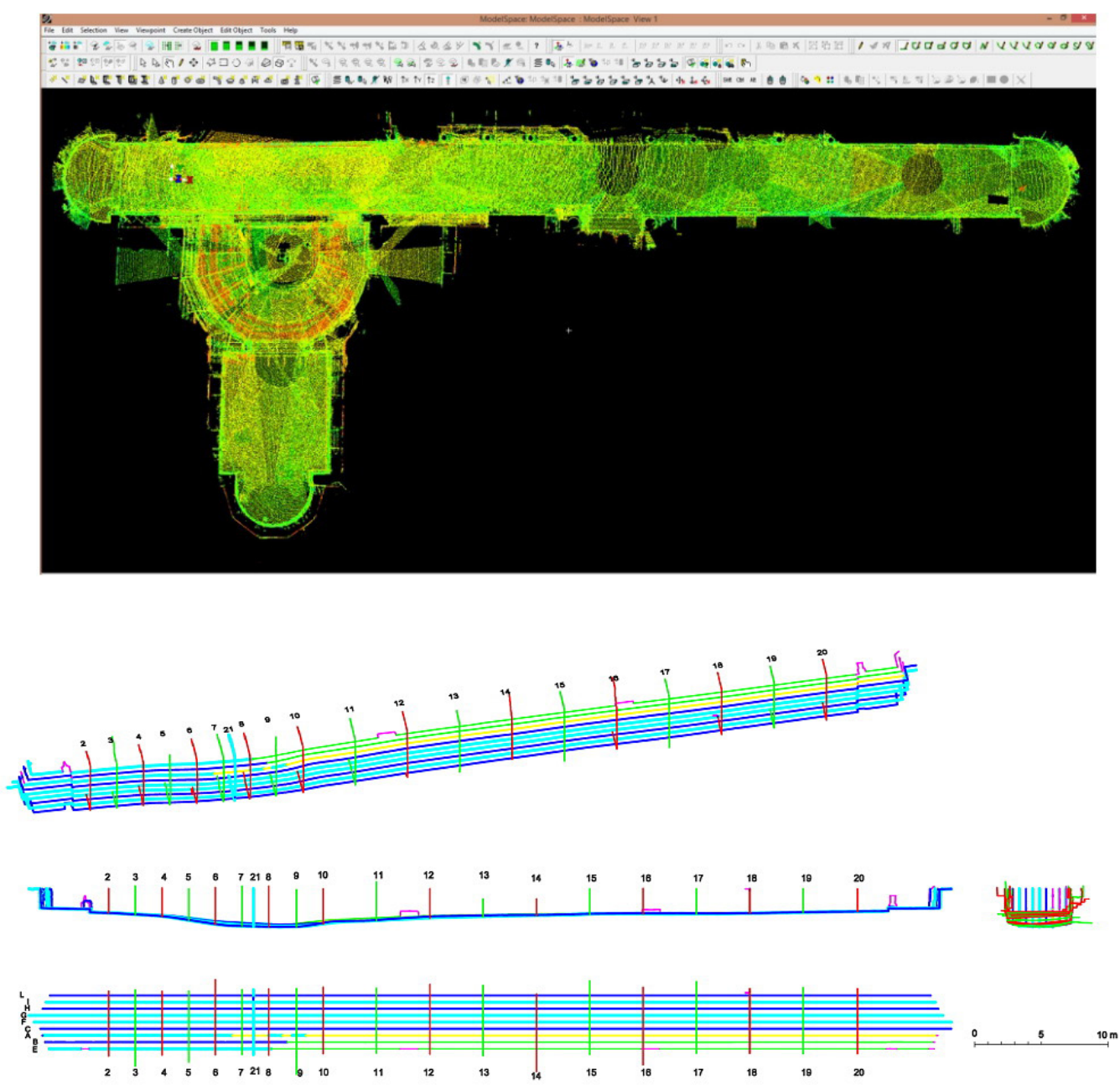
Probably in the third phase the basilica is also enlarged. The evolution suggests that the villa during the fourth century assumed a significant and particularly important role, in line with the nature of the client. The functional organization of the spaces is typical of late ancient Roman architecture, the arrangement over a large area of a set of buildings, arranged in a fan shape [Pellegrino 2007, pp. 33-39], fifty rooms, grouped into four complexes distinguished by their functions: the gym with the baths, the peristyle, various rooms used as living rooms with the guesthouse, the private rooms with the basilica, the tricora room and the elliptical courtyard.

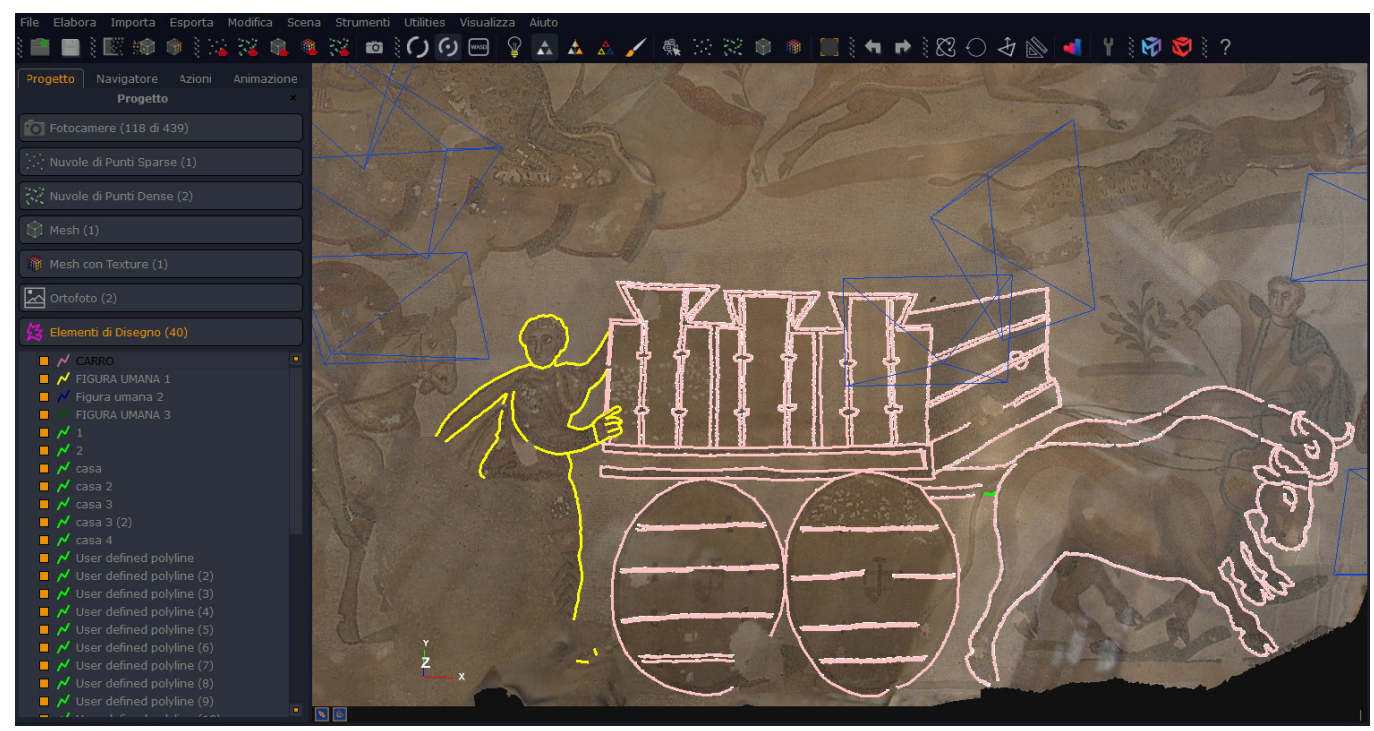

\section{The survey}

The typology of the survey was determined by the conditions and importance of the environments, for regular ones it was decided to use the direct survey. Photogrammetry and 3D laser scanner for those with particular geometries, such as the porticoed atrium with Arione's diatea, the basilica, the ovoid portico, the triapsidal triclinic and the ambulatory of the great hunt, for the latter the choice is derived from the need to investigate the variations in height of the floor on which the mosaics rest. Some aspects were then investigated, including the representation of the mosaics and the creation of $V R$ models.

\section{The representations of the mosaic floor of the two-apsidal ambulatory of the great hunt}

It is located along the eastern part of the peristyle, at a higher altitude through four elevations. The name derives from the theme of its mosaic, the adjective to distinguish it from the small hunting room [Sposito 2007, pp. 40-53]. The connection with the basilica is over half of its development and their relationship is not inseparable: the ambulatory represents a hinge element between public and private life, a prelude to the most authoritative environment of the villa. The mosaic is set on three registers, of which the upper one describes the natural landscape and the built environment, the middle one describes some hunting scenes and the lower one describes particular subjects. The representations contained are divided into 7 scenes and 18 panels, the reading proceeds from the north towards the axis of the basilica and from the south towards the same axis. The representations accompany the visitor, with a figurative path up to the entrance of the basilica, 
Fig. 6. Ambulacrum of the great hunt, restitution of artefact with exaltation of depth.

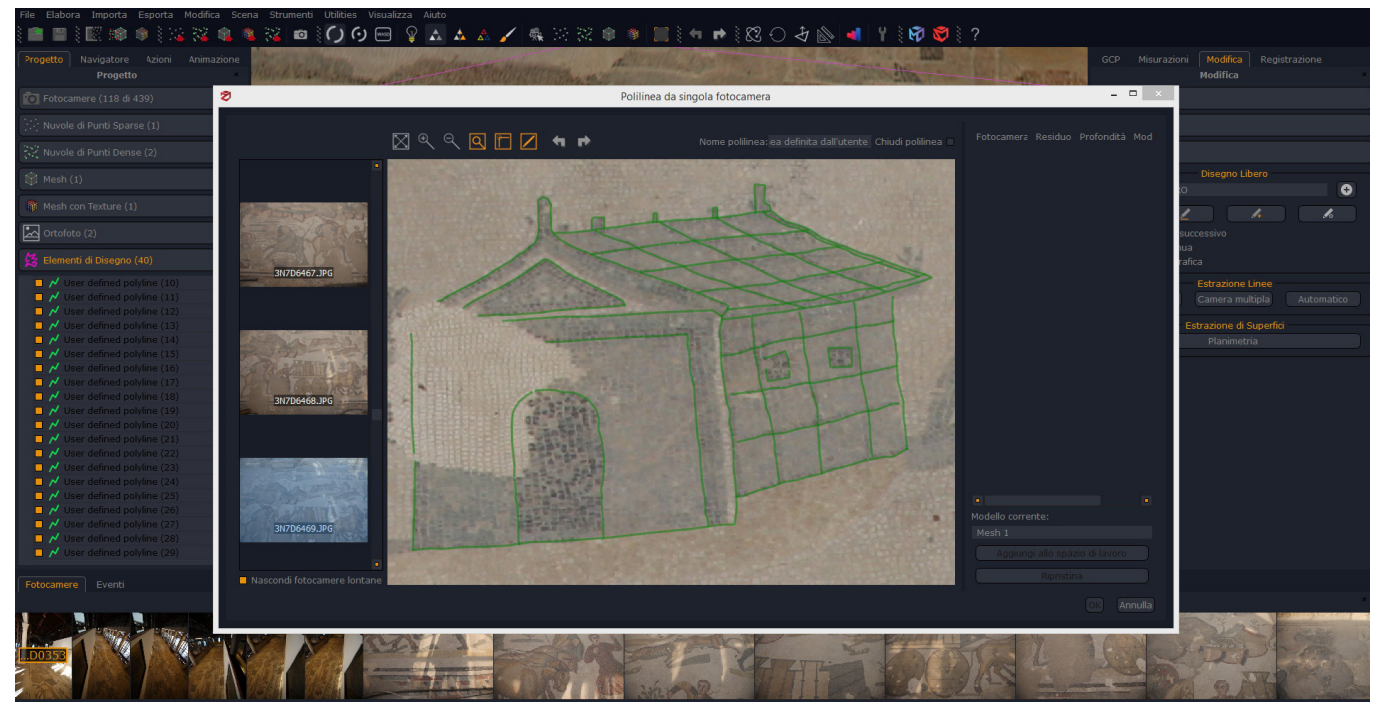

marked by two columns placed at a greater altitude. The scenes from the north towards the basilica can be summarized as follows: I. Africa, perhaps Mauritania, soldiers with shields and spears, the leopard and the lion; 2. the captures of a panther, antelope, lion and of the wild boar; 3. ostriches and antelopes, a city (possibly Carthage); 4. the loading of a ship, the unloading of an elephant in a land. In the opposite direction, from the south, i.e. from the right apse, towards the basilica: 5. India with the Asian elephant, the female tiger; 6. the capture of the griffin with human bait; 7. the capture of the tiger with the metal sphere; 8. a ship plowing the sea; 9. animals, beasts devouring an antelope; I0. an ox cart; I I. lion hunting with three soldiers; 12. a rhino and a hippopotamus; I3. a buffalo and an antelope in the Nile swamps; 14. Egypt with the port of Alexandria; I 5. an elephant a tiger and a dromedary; 16. a ship that loads an elephant and docks in a land; 17. a land between two seas; 18. an island: Sicily.

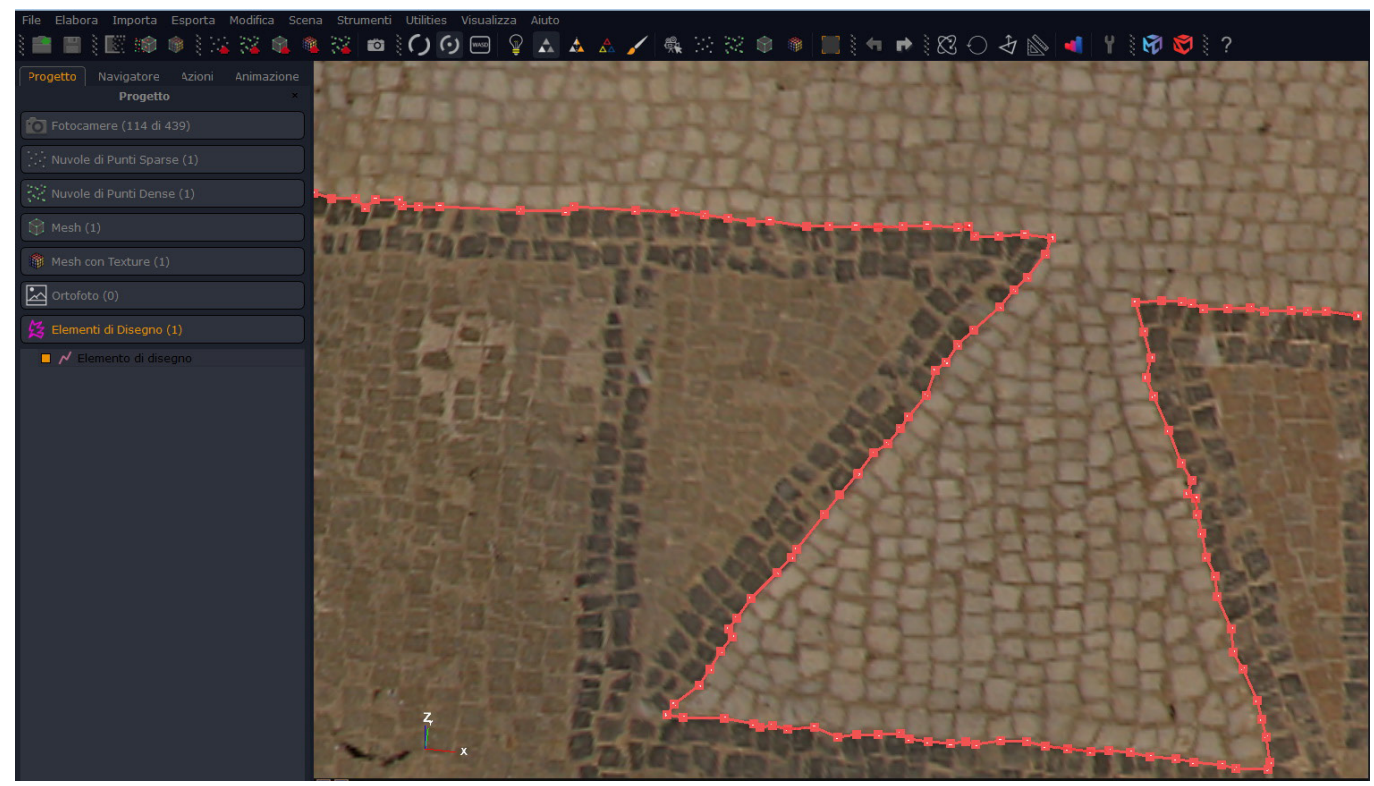


Fig. 8. Ambulacrum of the great hunt, the two dignitaries with

Pannonian headgear and staff, at the entrance to the basilica, other human figures proportionate to the hierarchy.
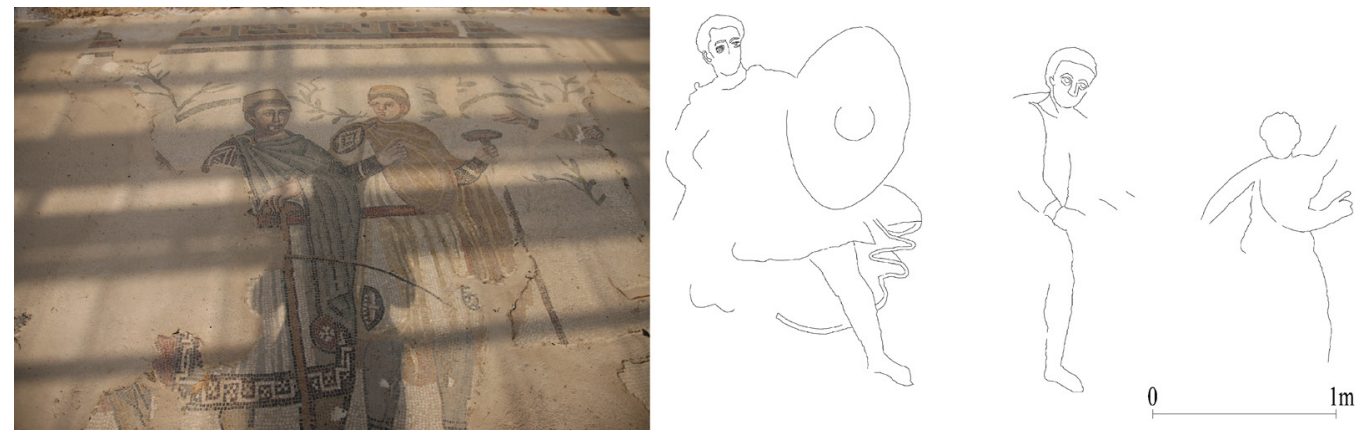

The survey of the ambulatory of the great hunt and the representation of the mosaic apparatus

The photogrammetry used is the multi-image one (SFM) validated for a better visualization of the mosaic apparatus, while five stations were performed with the laser scanner (fig. 4). Several workflows were analyzed:

- $\quad$ use the 3D laser scanner cloud for: mesh and texture with laser scanner images; upload some exterior photos with good detail.

- $\quad$ perform the straightening from a single image and compose a photomosaic,

- $\quad$ perform SFM multi-image photogrammetric processing, scaled with control points: draw on the 3D model; generate a scaled ortho-photo on which to draw

- create a multi-image photogrammetric SFM processing, scale the 3D model obtained by joining the laser scanner cloud: draw on the 3D model; generate an ortho-photo to draw on.

The first solution was discarded as the laser scanner photos always have a low degree of definition, as well as the photogrammetric straightening procedure as the dimensions of the ambulatory involve considerable photographic coverage, furthermore the lowering of the walking surface in the southern part measures negative values up to 1.30 meters, a situation not suited to photographic straightening. More generally, it was preferred to set up an automatic methodology acceptable in terms of time and precision, which would allow a control of the processing phases, a typical characteristic of SFM methodologies. Three programs were mainly used: 3Dflow's Zephyr, Agisoft's Metashape and CloudCompare (fig. 2) [I], obtaining different results. The preliminary orientation of several models required intervention on the parameters to obtain optimized results, combined with the alignment of a greater number of oriented photographs. The best results saw I I8 oriented images, then I30 and finally I40 on a set of 452. The average GSD of the panoramic photos was verified which was equal to $2.57 \mathrm{~cm} /$ pixel, which constitutes a good compromise between the graphic scale of the details of the figures and the size of the tiles equal to about 5-6 $\mathrm{mm}$ in the north and $6-8 \mathrm{~mm}$ in the south. Then the dense cloud was processed, the mesh with 1,342,237 vertices and 2,672,786 triangles, finally the texture. For the scaling of the model I I control points were inserted, the distances between some of them were entered and then residual errors were checked. The
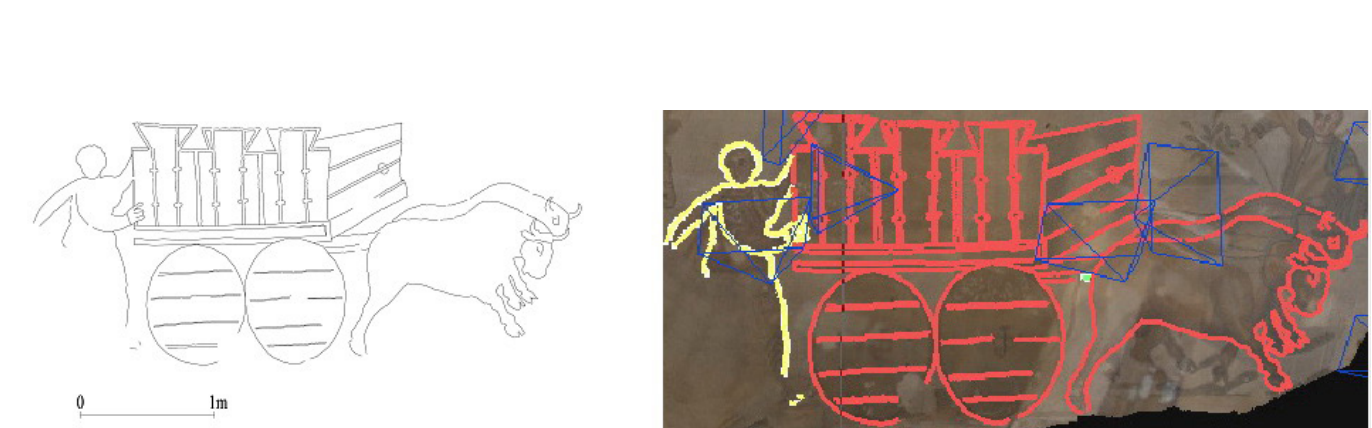
next phase was to combine the SFM cloud obtained from the photos with that of the 3D laser scanner, using the Zephyr software. Ten control points homologous to the first ten of the photogrammetric cloud processed previously were recorded. The rough alignment between the two clouds was performed using the homologous control points, then the ICP precision alignment, the maximum residual error between the two clouds was equal to $2 \mathrm{~mm}$.

Fig. 10. Ambulacrum of the Great Hunt, the depth in the representation of the built.

Fig.l I. Ambulacrum of the great fighter, the SFM model of about one third of the corridor starting from the north side.
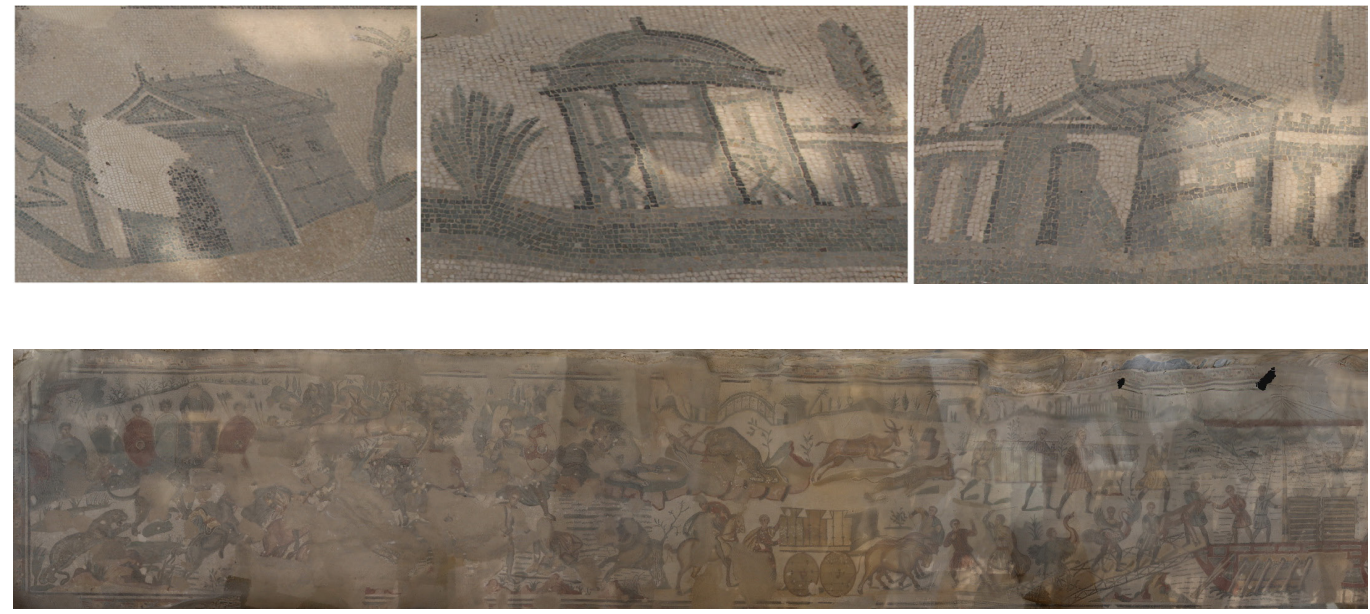

The graphic restitution

The restitution was set on the three-dimensional model (fig. 3), rather than on orthophotos, as the zephyr graphic edit allows you to draw both on the three-dimensional model processed as a textured mesh, and on individual photos (fig. 6), a very useful opportunity that allows you to follow the contours according to the image quality. The tracing mode on Zephyr provides for the creation of a polyline, for which the edge of the figures was followed in two different modes, what appeared irregular, the tracing followed the single mosaic tile, in the case of a regular edge the registration steps were greater (fig. 7). The restitution was organized in layers to distinguish the various human figures (fig. 8) and objects, among which the wagons with the towed animals (figs. 5,9 ) and simple artefacts were returned (figs. 6, I0). Different profiles were traced from the cloud obtained by laser scanner to study the variations in height of the walking surface (fig. 4).

\section{The results achieved}

In philosophiana's Roman villa everything is linked to the mystery rites, everything is a symbol, in every environment one of the different mysteries is treated. In the Orpheus diathe the theme of mosaic iconography is centered on orphism, in the triclinium the rite of Dionysus, Eros and Pan in the vestibule, so in the ambulatory of the great hunt the dominant theme is Mithraism linked to the oriental cult of Mitras. Furthermore, it is possible to identify some details to be connected only to trustees or in any case members of the imperial entourage, recent studies conducted on the occasion of the XVI AISCOM [2] Conference, have hypothesized that the owners of the villa may have been two Roman prefects, father and son, the This hypothesis derives from a very careful study of the mosaic, in which an elderly person appears with a Pannonian headdress, a symbol of power and another one next to it decorated in the same way, both at the entrance to the basilica. It would be Ceionius Rufus Volusianus, praefectus urbis and consul, at the time of Maxentius and Constantine, and his son Ceionius Rufus Albinus (fig. 8), known for his intellectual qualities, so much so as to deserve the epithet of philosophus. In addition to the headdress, one of the two carries a tau stick in his hand, a symbol of command authority as well as predestination, 
which finds a semantic analogy in a character from another villa, that of Tellaro in the territory of Noto (SR). The stick recalls the Eleusinian mysteries, an example of cultural syncretism between different mysterious philosophies such as the anticosmic orphism and Mithraism. Again the chlamys with at the height of the right arm a rhombus inscribed in a circumference with eight points marked on the sides of the rhombus that indicate the achievement of perfection: the octave leads beyond the seven spheres. The older character is attributed the characteristic of the owner, a sort of priest, teacher, philosopher who once remembered, through the allegories of hunting, the troubles overcome to reach spiritual elevation, prepared to enter the basilica to celebrate solemn liturgies from share with members of the intellectual and spiritual elite. Without wishing to discuss other characters and symbolisms even though they are present, we understand how the graphic analysis of this mosaic apparatus allows for a hitherto unusual reading. The first results made it possible to establish: the existence of a hierarchy of characters described through different measures of human figures, the search for the third dimension in some architectural artefacts (fig. I0) rather than in others, an aspect that gives meaning to places, a search for depth that enhances some objects. The dimensional difference between the human figures is based on the social hierarchy, the dimensions are increasing according to rank, but also the attention to detail and the sumptuousness of the ornaments. There are three hierarchies (fig. 8): the serviles, the soldiers and the aristocrats, even the relationships between the various parts of the body fall within the parameters of dimensional harmonies. Human figures are mainly represented in dynamic positions, in the act of performing an action, the body in front view to give as much space as possible to the representation of clothing, the face for some in front view for others in profile. Regarding the built, the sense of depth in the drawing favors some objects that are represented in a sort of axonometry (fig. I 0), others only in frontal projection. Among those in axonometry in some there is an attention to the attack on the ground in the sense of depth, for other representations the question is resolved in a hasty way, different the hypotheses of this dualism could be: a late makeover, different workers with different knowledge. Another graphic correspondence was the size and position of the two aristocratic characters with respect to the stairway leading to the basilica, as well as the correct geometry of the rhombus on the right arm of the two aristocratic figures and other characters. In future investigations the material and colorimetric aspects of the tiles will be studied, similarities and differences with contemporary mosaics in the same area will be sought, including the Villa del Tellaro, as well as the graphic rendering of the other rooms of the villa for the dimensional and formal analogies of the figures and esoteric symbols. Starting from the plants, a three-dimensional digital model of the villa was created with Sketch Up (fig. I 2), navigable from a PC and usable with viewers and smartphones, a model is being developed on Oculus Quest 2 and the creation of an immersive reality through two different quarries with two different workflows. The first cave has three walls, is managed by IE.ME.S.T. [3] and is under construction and involves the use of Meshlab and Unity3D, overcoming the problems with the Uni-CAVE plugin. The second quarry already operational was developed by SWING IT [4], it is two walls being expanded for the third wall and involves the use of TechViz as well as the use of wearable peripherals for immersive interaction.

\section{Conclusions}

The research activity of the Roman villa of Philosophiana involves more and more knowledge and disciplinary sectors, investigating new aspects. The largest mosaic of the villa depicts hunting scenes in the relationship with the three continents of the Mediterranean, in the center of which is the island of Sicily, in the center of which is the villa, in the center of which is the mosaic. The reading of this mosaic apparatus that has always captured the attention, reveals underlying messages that can be read through the graphic tool. The research activity described above is still ongoing with further developments including the intention of a drone shooting for a better quality of the photogrammetric coverage and the launch of the same investigation in the most ambitious mosaics of the other environments. Further virtualization initiatives of the mosaics and of the entire villa were undertaken for the processing of virtual reality $(V R)$ and augmented reality (AR), as part of a project funded by the Sicily region. 
Fig. 12. The villa of the farmhouse the 3D mode created with SketchUp, navigable with a PC and usable with smartphones.

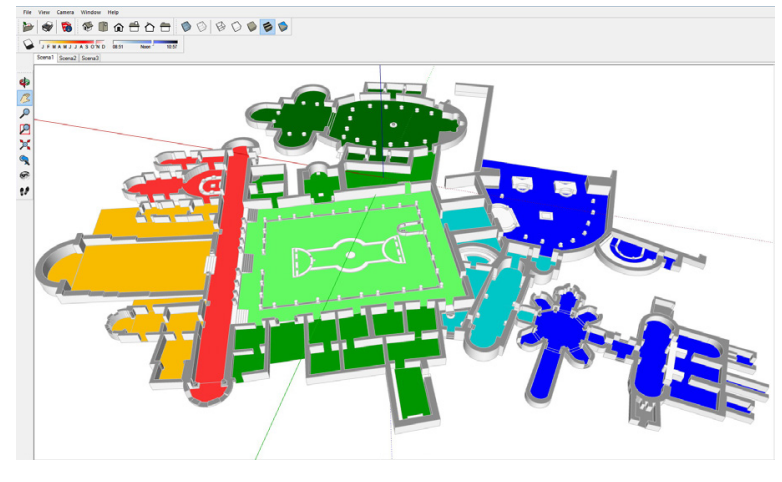

Credits

This work was supported by the project "Creazione di una rete regionale per l'erogazione di servizi innovativi basati su tecnologie avanzate di visualizzazione" (3DLab-Sicilia), Grant No. 08CT4669990220, funded by Operational Program 20 I4-2020 of the European Regional Development Fund (ERDF) of the Sicilian Region.

\section{Notes}

[I] Zephyr software is from 3Dflow, Metashape from Agisoft and are registered trademarks. CloudCompare is defined by a GNU General Public License (GPL)

[2] Italian Association for the Study and Conservation of Mosaics.

[3] IE.ME.S.T. - Istituto Euro Mediterraneo di Scienza e Tecnologia di Palermo, is one of the partners of the 3DLAB SICILIA project.

[4] SWING IT is the acronym or abbreviation of Software Engineering based in San Giovanni La Punta (CT), it is one of the partners of the 3DLAB SICILY project.

\section{References}

Benedetti B., Gaiani M., Remondino F. (20 I0). Modelli digitali 3D in archeologia: il caso di Pompei. Pisa: EAN.

Cammarata E. (20 I 6). L'antica Villa Romana del Casale di Piazza Armerina Verità Storiche e Curiosità. Messina: Edizione Avvenire. Docci M. (1987). Disegno e Analisi Grafica, Preistoria Grecia Roma. Bari: Laterza.

Farella E.M.R., Torresani A., Remondino F. (2019), Quality Features for integration of and UAV Images, Int. Arch. Photogramm. In Remote Sens. Spatial Inf. Sci, n. XLII-2N9, pp. 339-346.

Giangreco R. (20 I2). Villa Romana del Casale Viaggio tra i misteri. Assoro (EN): NovaGraf.

Grilli E., Remondino F. (2019). Classification of 3D Digital Heritage. In Remote Sens., n. I I, p. 847.

Meli G. (a cura di). (2007). La villa e gli apparati decorativi, Progetto di recupero e conservazione della Villa Romana del casale di Piazza Armerina, Centro Regionale per la progettazione e il Restauro. Palermo: CIP.

Pensabene P., Barresi P. (a cura di). (2019). Piazza Armerina Villa del Casale, scavi e studi nel decennio 2004-20 I 4. Roma: «L'ER$M A »$ di BRETSCHNEIDER.

Settis S. (1975). Per l'interpretazione di Piazza Armerina. In Melange de l'Ecole francaise de Rome, n. 87(2) LXXXVII, pp. 873-994. <https://www.persee.fr/doc/mefr_0223-5102_1975_num_87_2_5460> (accessed 2021, February 5).

Sposito A. (2007), L'Architettura della Villa del Casale, L'Ambulacro Biabsidato della grande Caccia. In Meli G. (a cura di). La villa e gli apparati decorativi. Progetto di recupero e conservazione della Villa Romana del casale di Piazza Armerina. Centro Regionale per la progettazione e il Restauro, CIP - Biblioteca centrale della Regione siciliana "Alberto Bombace", Palermo.

\section{Author}

Giuseppe Di Gregorio, Università degli Studi di Catania, giuseppe.digregorio@unict.it

To cite this chapter. Di Gregorio Giuseppe (202I). II disegno dei mosaici dell'ambulacro della Grande Caccia nella villa Philosophiana di Piazza Armerina/The Drawing of the Mosaic Ambulatory of the Great Hunt in the Philosophiana Villa in Piazza Armerina. In Arena A. Arena M. Mediati D. Raffa P (a cura di) Connettere Un disegno per annodare e tessere Linguagoi Distanze Tecnologie. Atti del $42^{\circ}$ Convegno Internazionale dei Docenti delle Discipline della Roppresentazione/Connecting. Drawing for whe national Conference of Representation Disciplines Teachers. Milano: FrancoAngeli, pp. 221 I-2230. 